\title{
AIRBORNE MAGNETIC GEOPHYSICAL SURVEY OF THE PORCUPINE RIVER AREA,
}

ALASKA

Emond, A.M., Graham, G.R.C., Drenth, B.J., Jones, J.V.III., and EON Geosciences Inc.

Geophysical Report 2019-1

2019

STATE OF ALASKA

DEPARTMENT OF NATURAL RESOURCES

DIVISION OF GEOLOGICAL \& GEOPHYSICAL SURVEYS

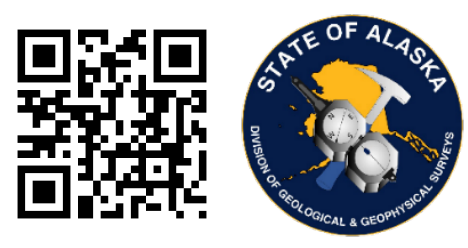


STATE OF ALASKA

Michael J. Dunleavy, Governor

DEPARTMENT OF NATURAL RESOURCES

Corri A. Feige, Commissioner

DIVISION OF GEOLOGICAL \& GEOPHYSICAL SURVEYS

Steve Masterman, State Geologist \& Director

Publications produced by the Division of Geological \& Geophysical Surveys are available to download from the DGGS website (dggs.alaska.gov). Publications on hard-copy or digital media can be examined or purchased in the Fairbanks office:

Alaska Division of Geological \& Geophysical Surveys (DGGS)

3354 College Road | Fairbanks, Alaska 99709-3707

Phone: 907.451.5010 | Fax 907.451.5050

dggspubs@alaska.gov $\mid$ dggs.alaska.gov

DGGS publications are also available at:

Alaska State Library, Historical

Collections \& Talking BookCenter

395 Whittier Street

Juneau, Alaska 99801

Alaska Resource Library and

Information Services (ARLIS)

3150 C Street, Suite 100

Anchorage, Alaska 99503

\section{Suggested citation:}

Emond, A.M., Graham, G.R.C., Drenth, B.J., Jones, J.V.III., and EON Geosciences Inc., 2019, Airborne magnetic geophysical survey of the Porcupine River area, Alaska: Alaska Division

of Geological \& Geophysical Surveys Geophysical Report 2019-1, 1 DVD.

http://doi.org/10.14509/29737
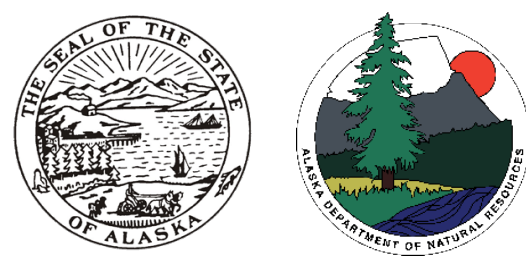


\section{AIRBORNE MAGNETIC GEOPHYSICAL SURVEY OF THE PORCUPINE RIVER AREA, ALASKA \\ Emond, A.M., ${ }^{1}$ Graham, G.R.C., ${ }^{1}$ Drenth, B.J., ${ }^{2}$ Jones, J.V.III., ${ }^{3}$ and EON Geosciences Inc.}

\section{ABSTRACT}

The Porcupine River fixed wing aeromagnetic geophysical survey is located in eastern Alaska, along the Canadian border, in the Sheenjek and Black mining districts. This survey is located about 135 kilometers east of Fort Yukon, Alaska and about 85 kilometers east of Circle, Alaska. Magnetic data were collected with a Geometrics G-822A cesium-vapor split-beam sensor mounted in a tail stinger. Between May 5th and June 28th, 2017, a total of 50,329 line kilometers were collected covering 13,646.9 square kilometers. Data were collected at a line spacing of 300 meters $(\mathrm{m})$ with a mean ground clearance of $235 \mathrm{~m}$.

\section{PURPOSE}

The survey data will be used by USGS, DGGS, and other researchers to better understand the crustal suture between Arctic Alaska and North America. Both the North American and Arctic Alaska successions contain rift- and arc-related volcanic and plutonic rocks associated with substantial mineral endowment farther west in the Brooks Range and to the east in the Selwyn Basin of Yukon Territory. The boundary of the two terranes is inferred to lie in a broad corridor parallel to the Porcupine River near where it crosses the international border. The data will also assist with evaluation of the mineral-resource potential for landmanagement planning.

\section{SURVEY OVERVIEW DESCRIPTION}

This document provides an overview of the survey and includes text and figures of select primary and derivative products of this survey. A table of digital data packages available for download is provided to assist users in data selection. For reference a catalog of the available maps is presented in reduced resolution. Please consult the metadata, project report, and digital data packages for more information and data.

\section{ACKNOWLEDGMENTS}

Funding was provided by the U. S. Geological Surveys Mineral Resources Program. USGS grant: G16AC00169.

\footnotetext{
${ }^{1}$ Alaska Division of Geological \& Geophysical Surveys, 3354 College Road, Fairbanks, Alaska 99709-3707

${ }^{2}$ Geology, Geophysics, and Geochemistry Science Center, W $6^{\text {th }}$ Ave Kipling St., P.O. Box 25046, MS 964, Denver, CO 80225

${ }^{3}$ Alaska Science Center, 4210 University Drive, Anchorage, AK 99508
} 


\begin{tabular}{|c|c|c|}
\hline Data Type & Provider & Description \\
\hline ascii_data & contractor & ASCII format line data, other ASCII data \\
\hline databases_geosoft & contractor & $\begin{array}{l}\text { Geosoft format database of line data, other Geosoft } \\
\text { format databases }\end{array}$ \\
\hline documents & contractor and DGGS & $\begin{array}{l}\text { Project and field reports, survey background } \\
\text { information, gridded data explanations, other } \\
\text { supporting documentation }\end{array}$ \\
\hline grids_ermapper & contractor and DGGS & $\begin{array}{l}\text { Geographically registered gridded data, ER Mapper } \\
\text { ERS format }\end{array}$ \\
\hline grids_geosoft & contractor and DGGS & $\begin{array}{l}\text { Geosoft-format grids, these grids can be viewed in } \\
\text { ESRI ArcMap using a free plugin from Geosoft }\end{array}$ \\
\hline images_registered & DGGS & GeoTiff format images of gridded data \\
\hline $\mathrm{kmz}$ & DGGS & $\begin{array}{l}\text { keyhole markup language }(\mathrm{kml}) \mathrm{kmz} \text { archive files of } \\
\text { project data. Viewable in Google Earth and other } \\
\text { compatible programs }\end{array}$ \\
\hline maps_pdf_format & contractor & Printable maps in pdf format \\
\hline vector_data & contractor and DGGS & $\begin{array}{l}\text { Line path, data contours, and survey boundary in } \\
\text { ESRI shape file (SHP) format, ESRI Geodatabase } \\
\text { format, and/or AutoCAD dxf format }\end{array}$ \\
\hline video_flightpath & contractor & Survey flight path downward facing video \\
\hline
\end{tabular}




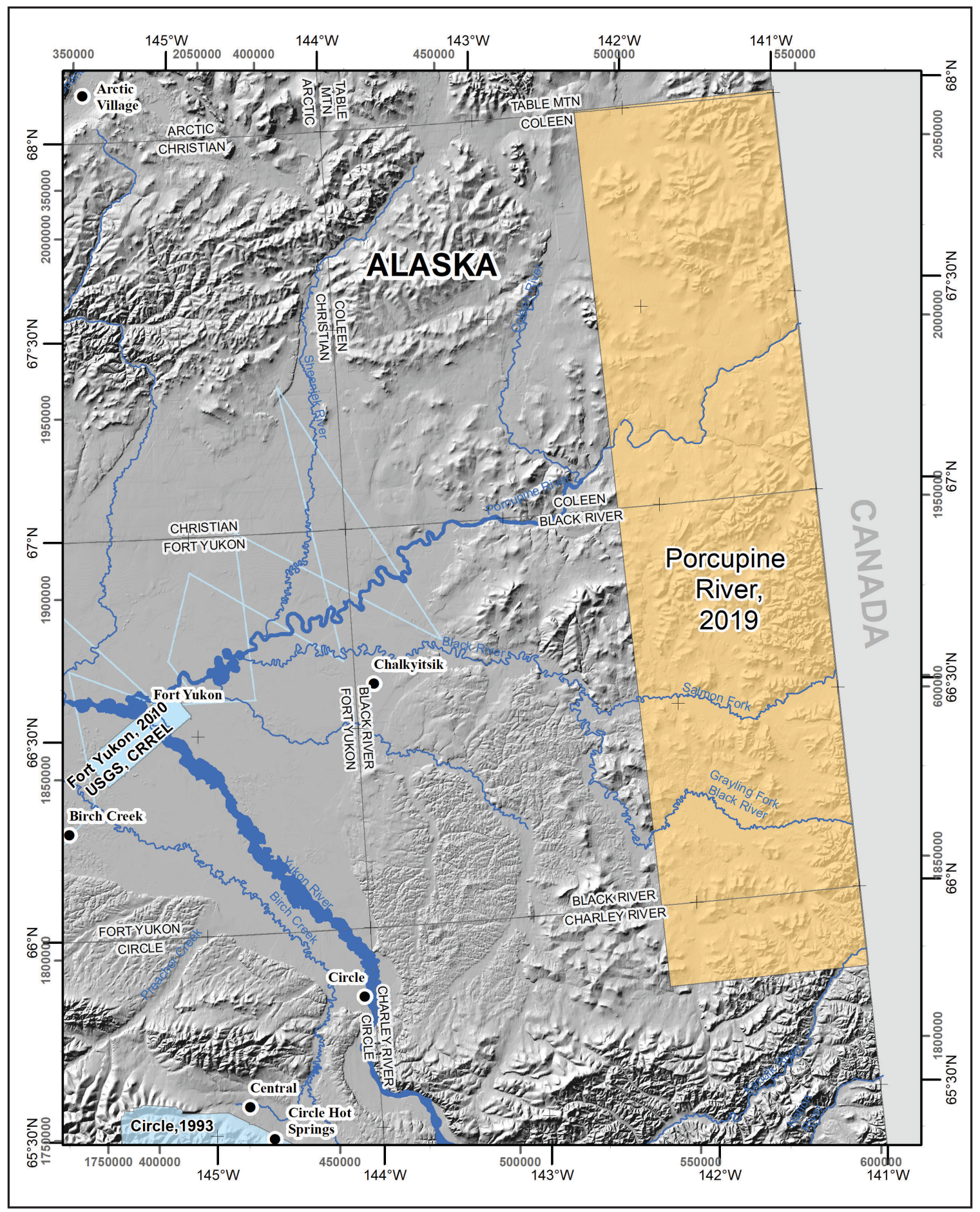

Figure 1. Porcupine River magnetic airborne geophysical survey location shown in north eastern Alaska (right). Porcupine River survey area shown with adjacent DGGS geophysical surveys, landmarks, relevant 1:250,000-scale quadrangle boundaries, mountain ranges, rivers, glaciers, and elevation hillshade. 


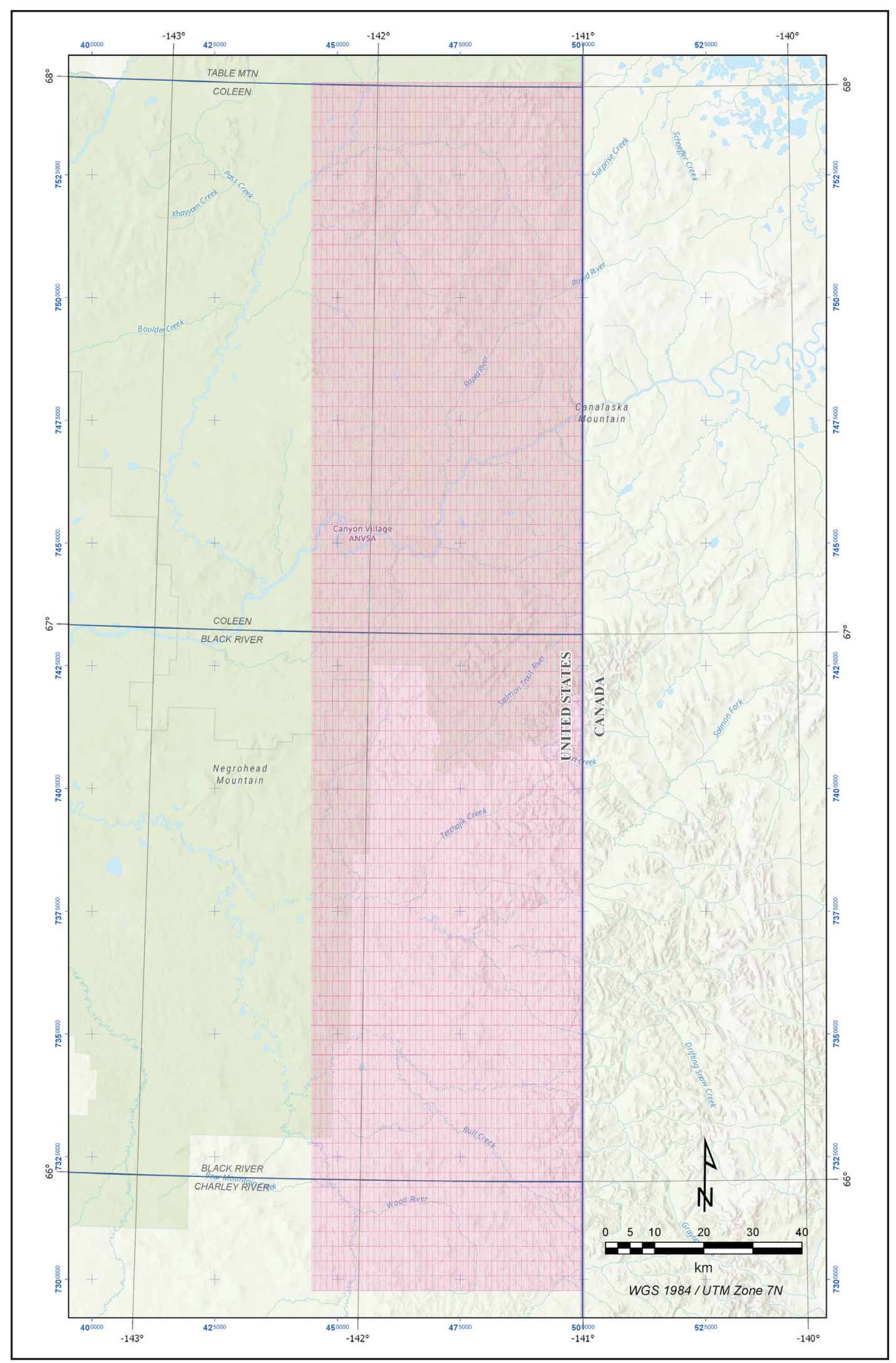

Figure 2. The final flight path was recovered following post-flight differential corrections which improve positioning accuracy to the sub-meter level. Additional onboard equipment included a FreeFlight Systems TRA-3500 radar altimeter, a Vaisala PTB110 barometric altimeter, and a vertically mounted video camera. Ground based systems included two GEM Systems GSM-19W Overhauser magnetometers and a NovAtel DL-V3 GNSS receiver. 


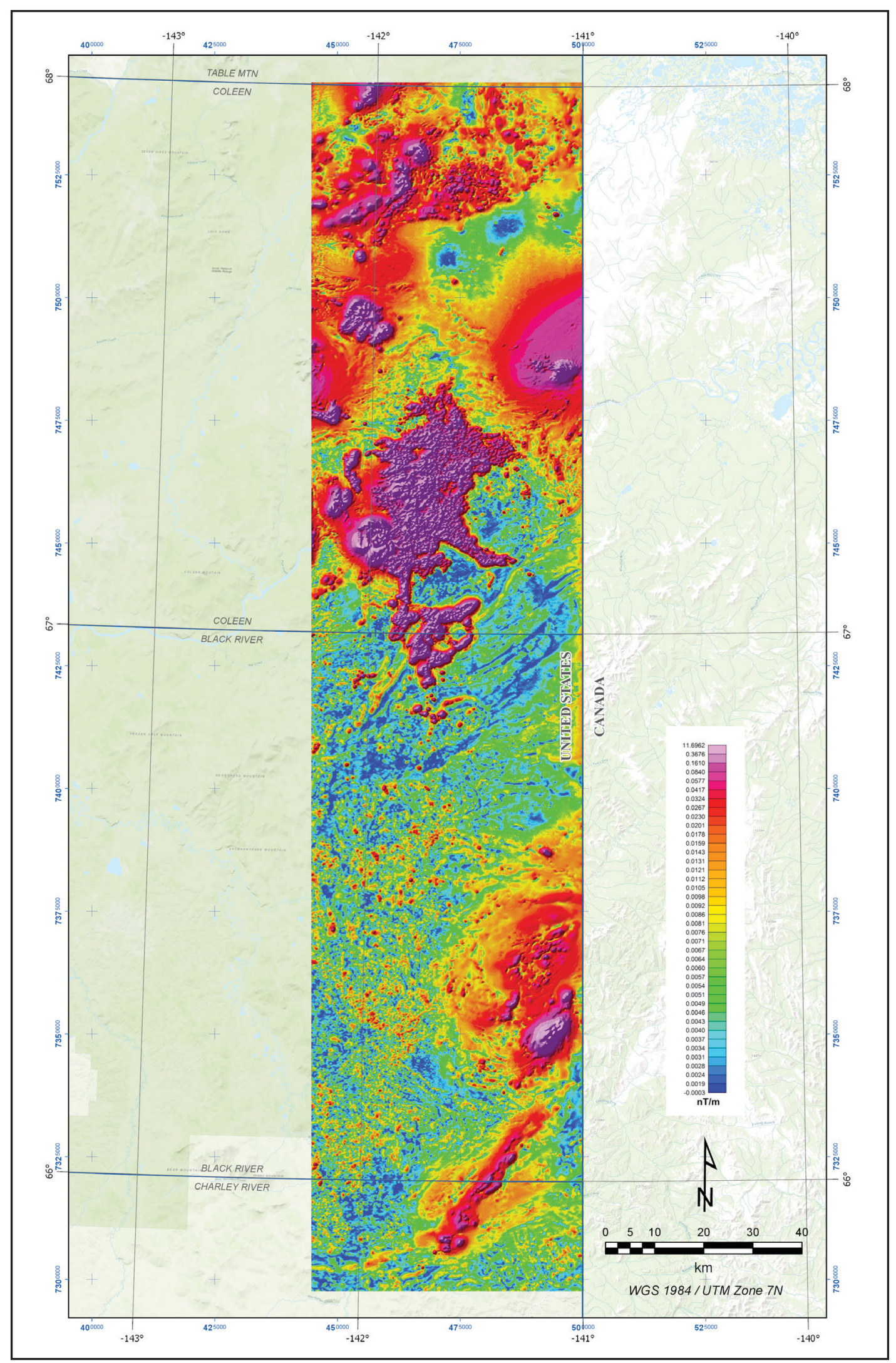

Figure 3. The analytic signal of the magnetic field is the total amplitude of the vector sum of the horizontal and vertical magnetic gradients. Computation of the analytic signal enhances the boundaries of magnetic anomalies and is independent of direction of magnetization. The data presented here were calculated from the residual magnetic intensity grid by: (1) computation of the total magnitude of the components obtained from the application of horizontal and FFT-based vertical derivative transfer functions, and (2) sampling this initial grid back into the line database and re-gridding the sampled data in order to attenuate the artefacts generated between traverse lines during gridding and FFT computations. 


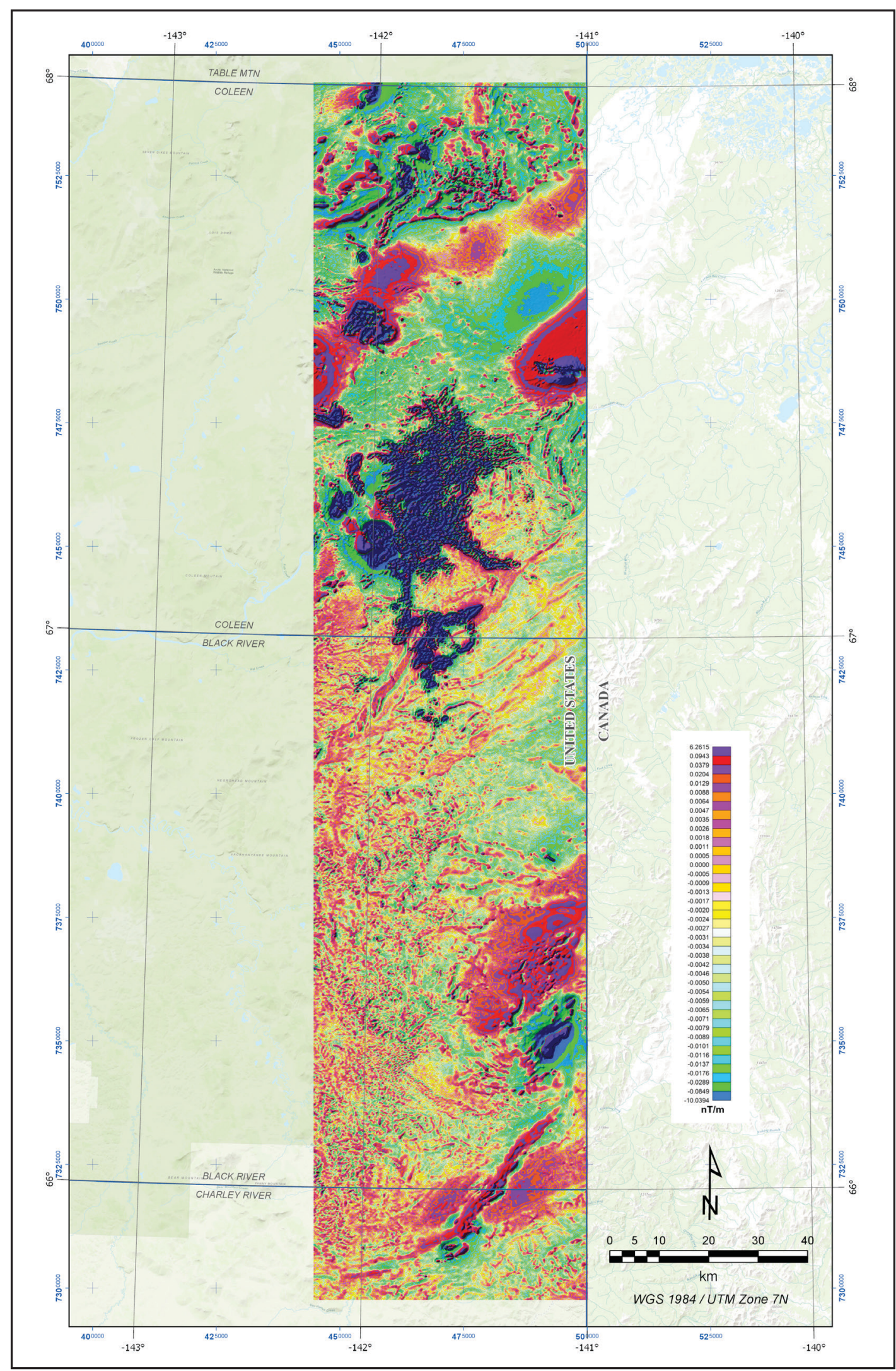

Figure 4. The first vertical derivative of the magnetic field is the rate of change of the magnetic field in the vertical direction. Computation of the first vertical derivative enhances shorter wavelength features and improves resolutions of closely spaced and superimposed anomalies. The data presented here were calculated from the residual magnetic intensity grid by (1) application of an FFT-based vertical derivative transfer function and (2) sampling this initial grid back into the line database and re-gridding the sampled data in order to attenuate the artefacts generated between traverse lines during gridding and FFT computations. 


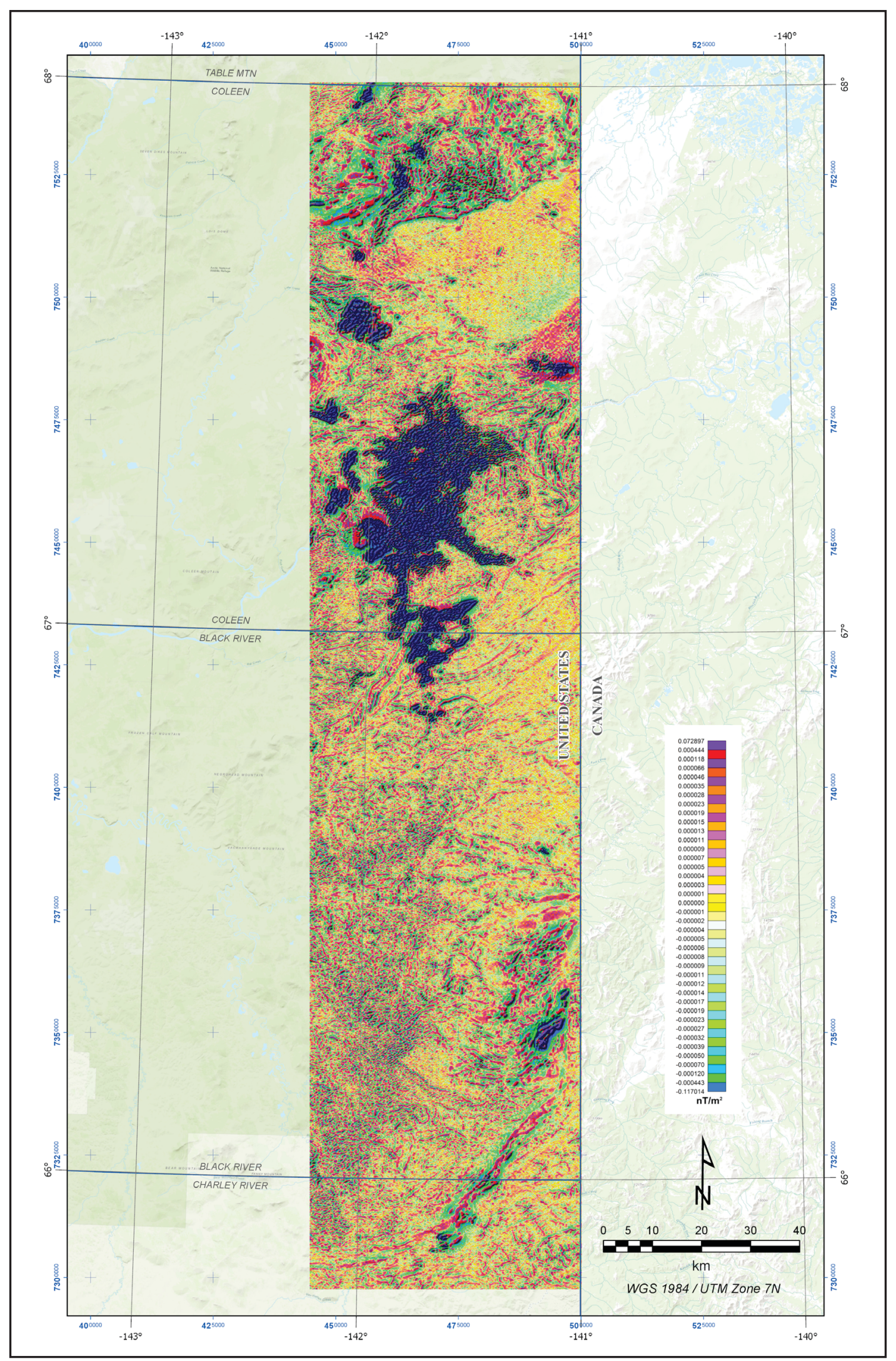

Figure 5. The second vertical derivative of the magnetic field is the curvature of the magnetic field with respect to the vertical direction. Computation of the second vertical derivative enhances shorter wavelength features and improves resolutions of closely spaced and superimposed anomalies. The data presented here were calculated from the residual magnetic intensity grid by (1) application of an FFT-based vertical derivative transfer function and (2) sampling this initial grid back into the line database and re-gridding the sampled data in order to attenuate the artefacts generated between traverse lines during gridding and FFT computations. 


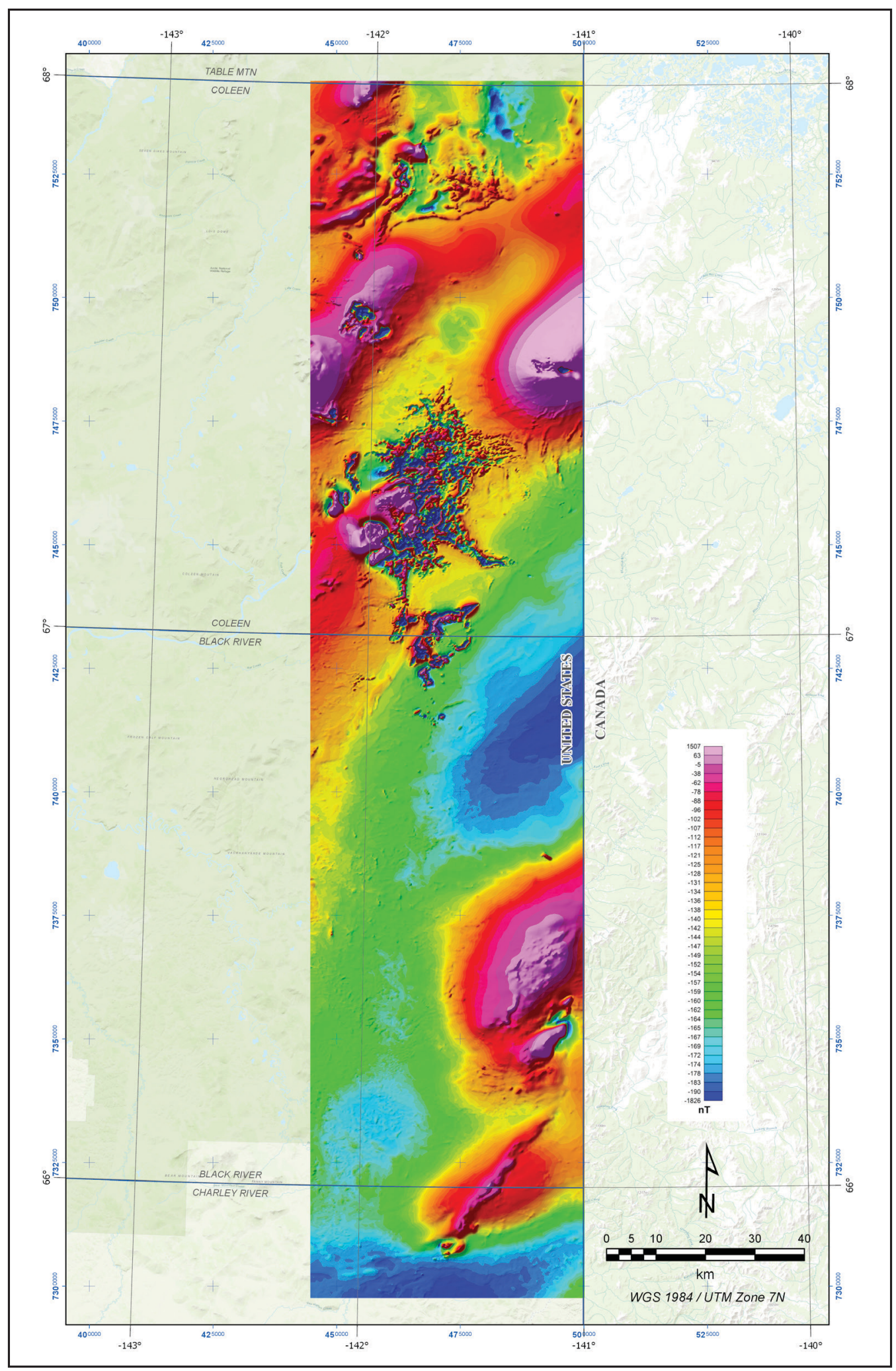

Figure 6. The residual magnetic field represents the component of the total magnetic field related almost entirely to the magnetic properties of the Earth's crust. The data presented here were derived from the recorded data by: (1) application of a lag to compensate for system latency, (2) correction against discrete spikes and high-frequency residual compensation noise, (3) application of a height correction derived from the International Geomagnetic Reference Field (IGRF) computed for flight and drape surfaces, (4) application of a diurnal correction derived from the magnetic base station data, (5) analysis of the remaining differences between the traverse and control line values at the intersection points to obtain a correction profile that results in mutually levelled line data, (6) application of a micro-levelling correction to further reduce residual noise, and (7) removal of the IGRF values defined at the average mean sea-level height of $690.0 \mathrm{~m}$ for a fixed date of June $1 \mathrm{st} 2017$ to obtain the residual magnetic intensity. The final residual magnetic field was then gridded at a cell size of $60 \mathrm{~m}$, using data from the traverse lines only. 


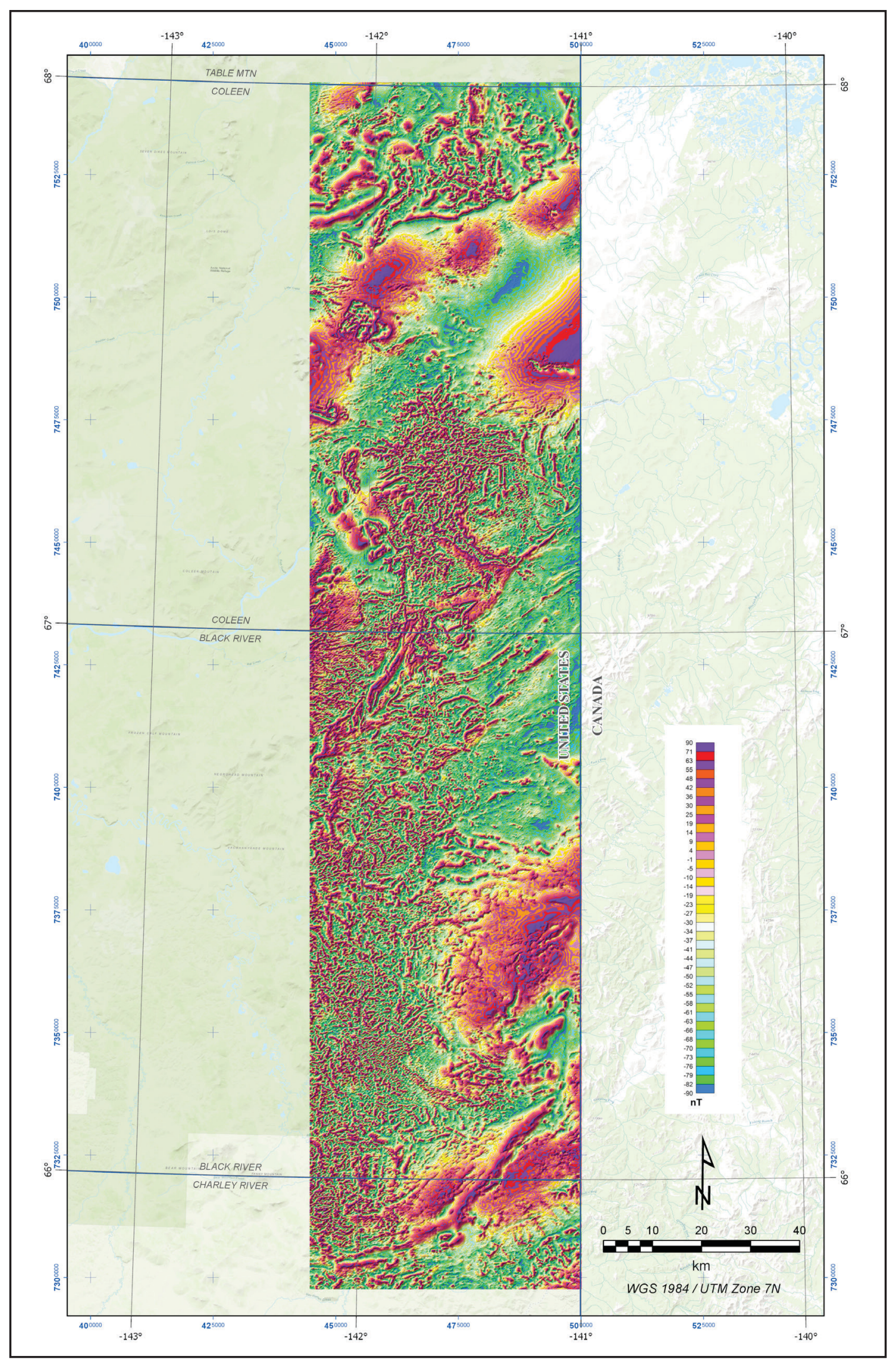

Figure 7. The tilt derivative of the magnetic field is its angle in the vertical direction with respect to the horizontal gradient. Computation of the tilt derivative is independent of magnetic intensity and depth to source, and therefore enhances weaker magnetic anomalies. The data presented here were calculated from the residual magnetic intensity grid by the application of horizontal and FFT-based vertical derivative transfer functions, and computation of the angle between the resulting components. 
Table 1. Copies of the following maps are included at the end of this booklet. The low-resolution, page-size maps included in this booklet are intended to be used as a search tool and are not the final product. Large-scale, full-resolution versions of each map are available to download on this publication's citation page: http://doi.org/10.14509/29737.

\begin{tabular}{|c|c|}
\hline Map Title & Description \\
\hline porcupine_analyticsignal_1 of4.pdf & analytic signal of the residual magnetic intensity with data contours and topographic base map \\
\hline porcupine_analyticsignal_2of4.pdf & analytic signal of the residual magnetic intensity with data contours and topographic base map \\
\hline porcupine_analyticsignal_3of4.pdf & analytic signal of the residual magnetic intensity with data contours and topographic base map \\
\hline porcupine_analyticsignal_4of4.pdf & analytic signal of the residual magnetic intensity with data contours and topographic base map \\
\hline porcupine_calculated1vd_1 of 4. pdf & calculated first vertical derivative of the residual magnetic intensity with data contours and topographic base map \\
\hline porcupine_calculated1vd_2of4.pdf & calculated first vertical derivative of the residual magnetic intensity with data contours and topographic base map \\
\hline porcupine_calculated1vd_3of4.pdf & calculated first vertical derivative of the residual magnetic intensity with data contours and topographic base map \\
\hline porcupine_calculated1vd_4of4.pdf & calculated first vertical derivative of the residual magnetic intensity with data contours and topographic base map \\
\hline porcupine_calculated2vd_1 of4.pdf & calculated second vertical derivative of the residual magnetic intensity with data contours and topographic base map \\
\hline porcupine_calculated2vd_2of4.pdf & calculated second vertical derivative of the residual magnetic intensity with data contours and topographic base map \\
\hline porcupine_calculated2vd_3of4.pdf & calculated second vertical derivative of the residual magnetic intensity with data contours and topographic base map \\
\hline porcupine_calculated2vd_4of4.pdf & calculated second vertical derivative of the residual magnetic intensity with data contours and topographic base map \\
\hline porcupine_digital_terrain_model_1of4.pdf & digital terrain model with topographic base map \\
\hline porcupine_digital_terrain_model_2of4.pdf & digital terrain model with topographic base map \\
\hline porcupine_digital_terrain_model_3of4.pdf & digital terrain model with topographic base map \\
\hline porcupine_digital_terrain_model_4of4.pdf & digital terrain model with topographic base map \\
\hline porcupine_flightlines_1of4.pdf & flightlines with topographic base map \\
\hline porcupine_flightlines_2of4.pdf & flightlines with topographic base map \\
\hline porcupine_flightlines_3of4.pdf & flightlines with topographic base map \\
\hline porcupine_flightlines_4of4.pdf & flightlines with topographic base map \\
\hline porcupine_ground_clearance_1of4.pdf & ground clearance with topographic base map \\
\hline porcupine_ground_clearance_2of4.pdf & ground clearance with topographic base map \\
\hline porcupine_ground_clearance_3of4.pdf & ground clearance with topographic base map \\
\hline porcupine_ground_clearance_4of4.pdf & ground clearance with topographic base map \\
\hline porcupine_residualmag.pdf & residual magnetic intensity grid with topographic base map \\
\hline porcupine_residualmag_1 of4.pdf & residual magnetic intensity grid with data contours and topographic base map \\
\hline porcupine_residualmag_2of4.pdf & residual magnetic intensity grid with data contours and topographic base map \\
\hline porcupine_residualmag_3of4.pdf & residual magnetic intensity grid with data contours and topographic base map \\
\hline porcupine_residualmag_4of4.pdf & residual magnetic intensity grid with data contours and topographic base map \\
\hline porcupine_tiltderivative_1 of 4 .pdf & magnetic tilt derivative of the residual magnetic intensity with data contours and topographic base map \\
\hline porcupine_tiltderivative_2of4.pdf & magnetic tilt derivative of the residual magnetic intensity with data contours and topographic base map \\
\hline porcupine_tiltderivative_3of4.pdf & magnetic tilt derivative of the residual magnetic intensity with data contours and topographic base map \\
\hline porcupine_tiltderivative_4of4.pdf & magnetic tilt derivative of the residual magnetic intensity with data contours and topographic base map \\
\hline
\end{tabular}



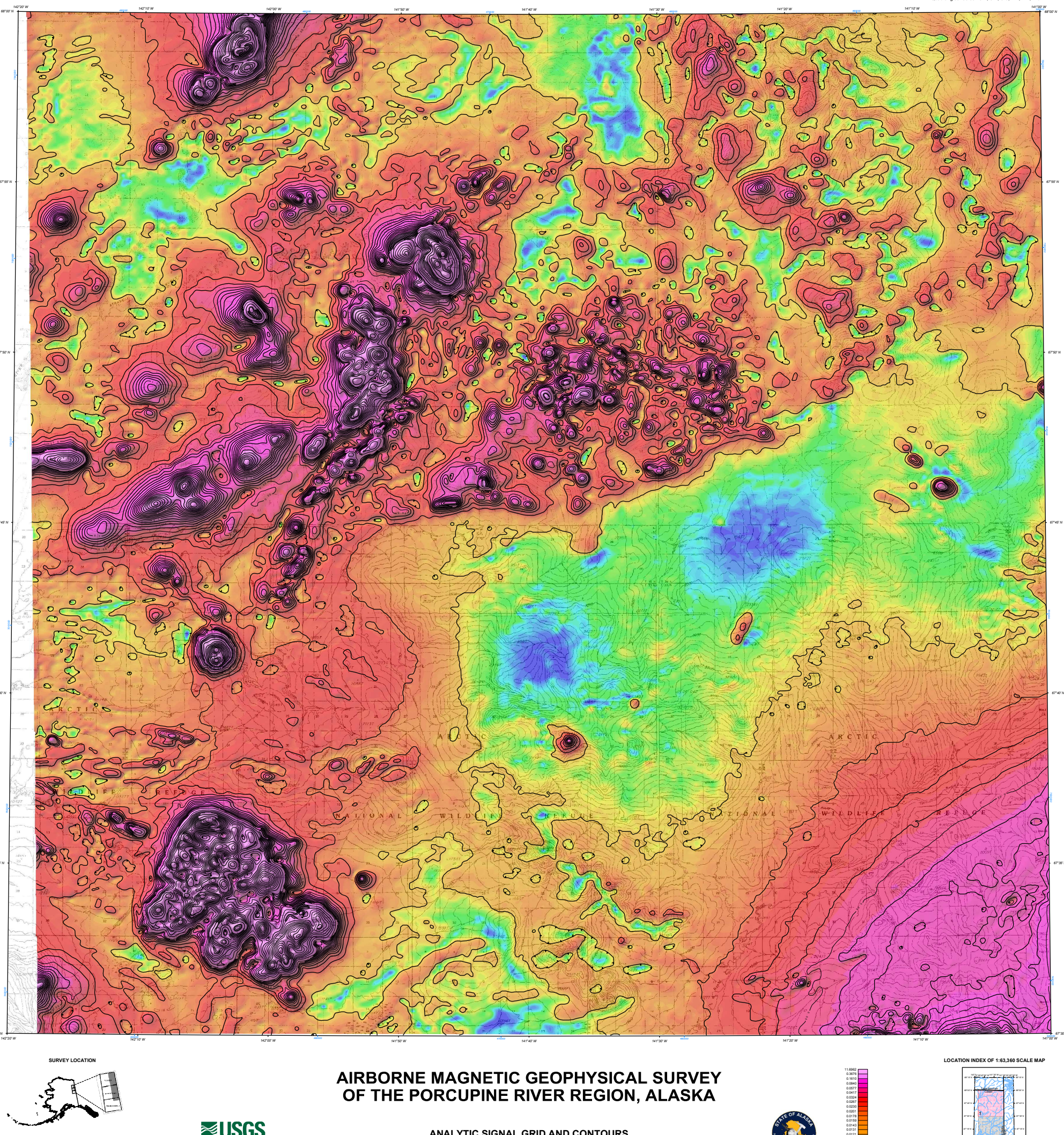

AIRBORNE MAGNETIC GEOPHYSICAL SURVEY OF THE PORCUPINE RIVER REGION, ALASKA

₹USGS

ANALYTIC SIGNAL GRID AND CONTOURS

http://doi.org/10.14509/29737
by EON Geosciences Inc.
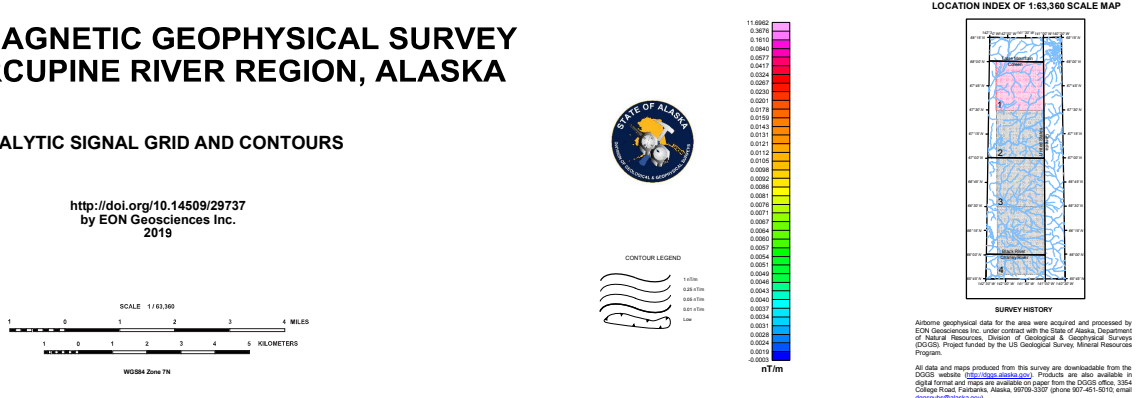


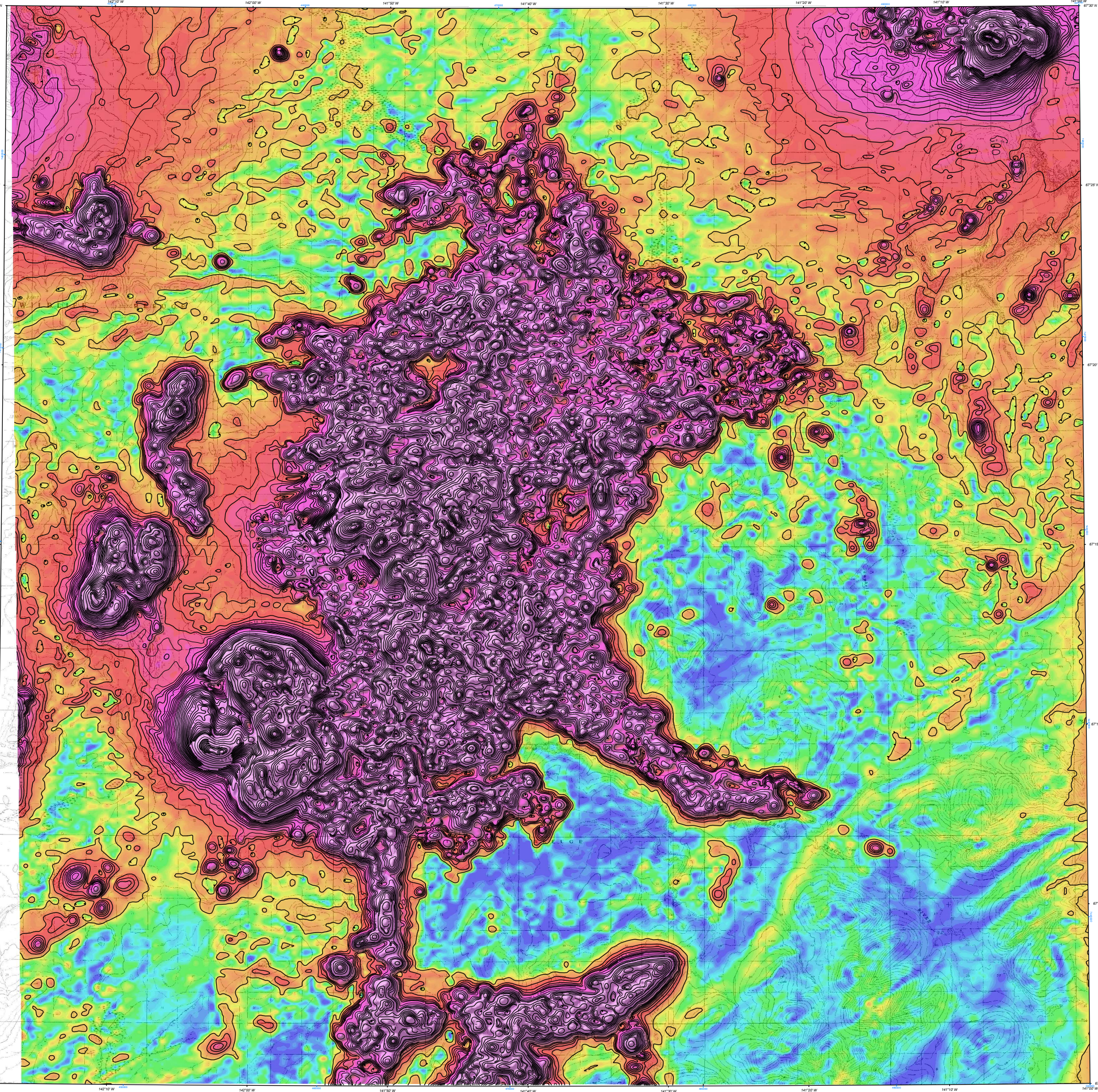

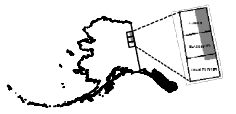

ॠUSGS

\section{AIRBORNE MAGNETIC GEOPHYSICAL SURVEY OF THE PORCUPINE RIVER REGION, ALASKA}

ANALYTIC SIGNAL GRID AND CONTOURS
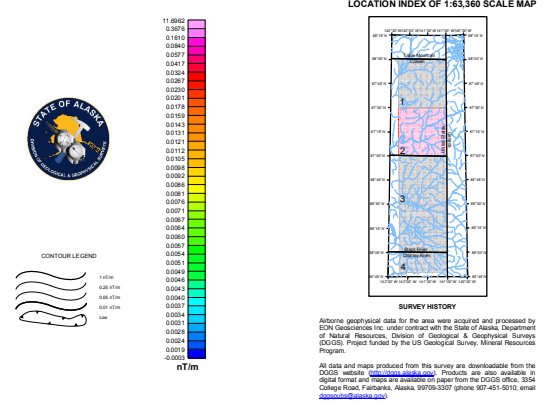


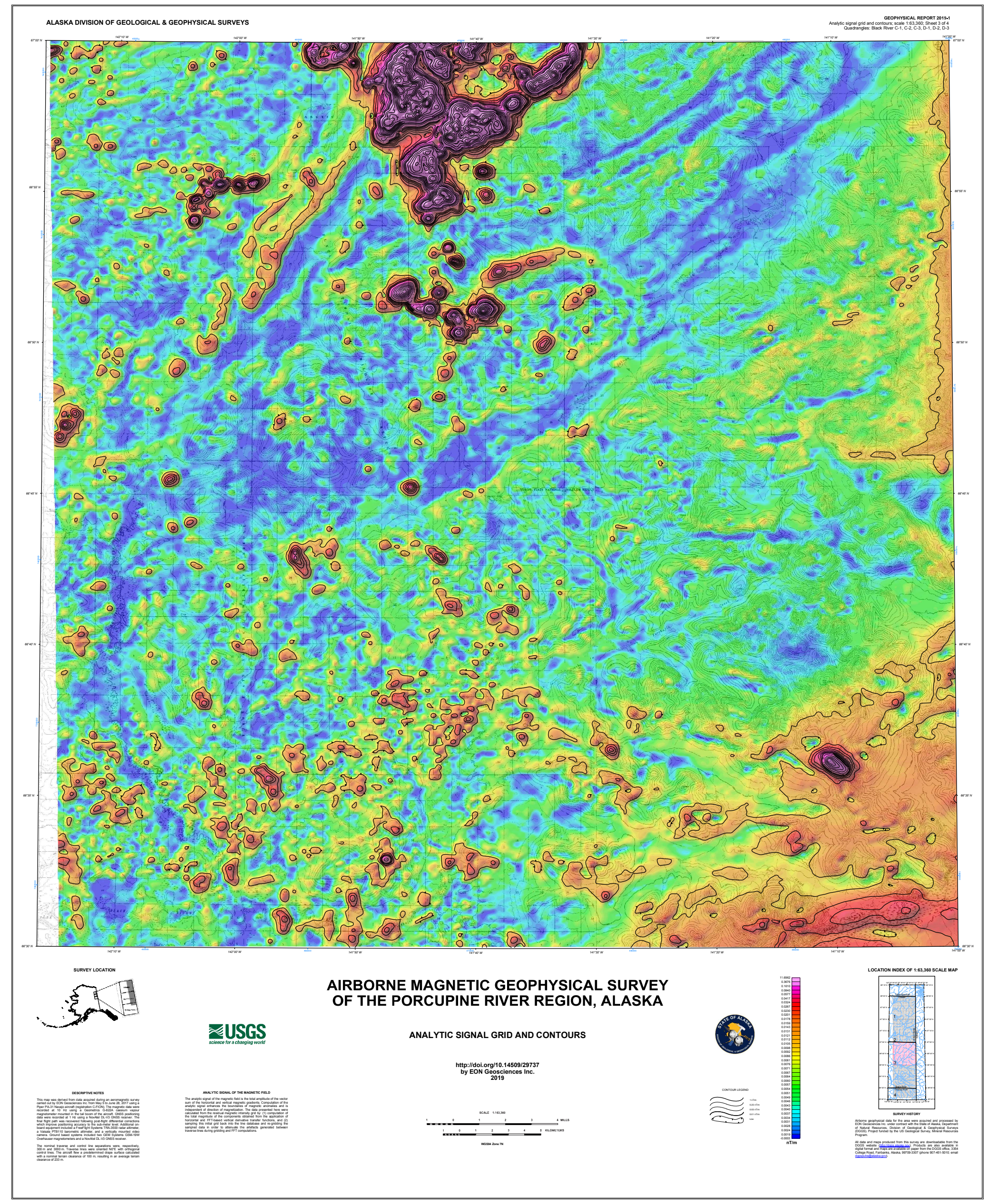




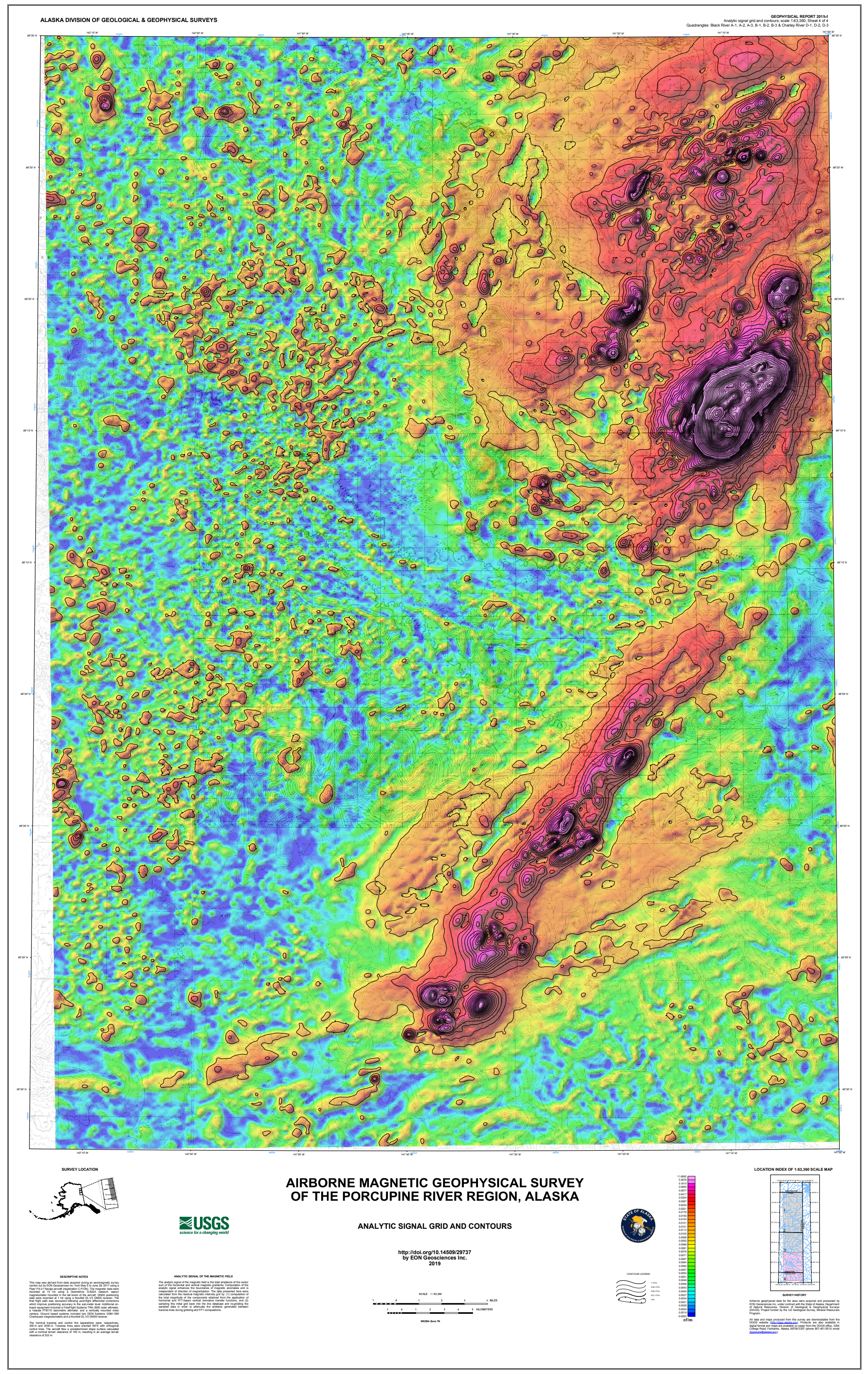




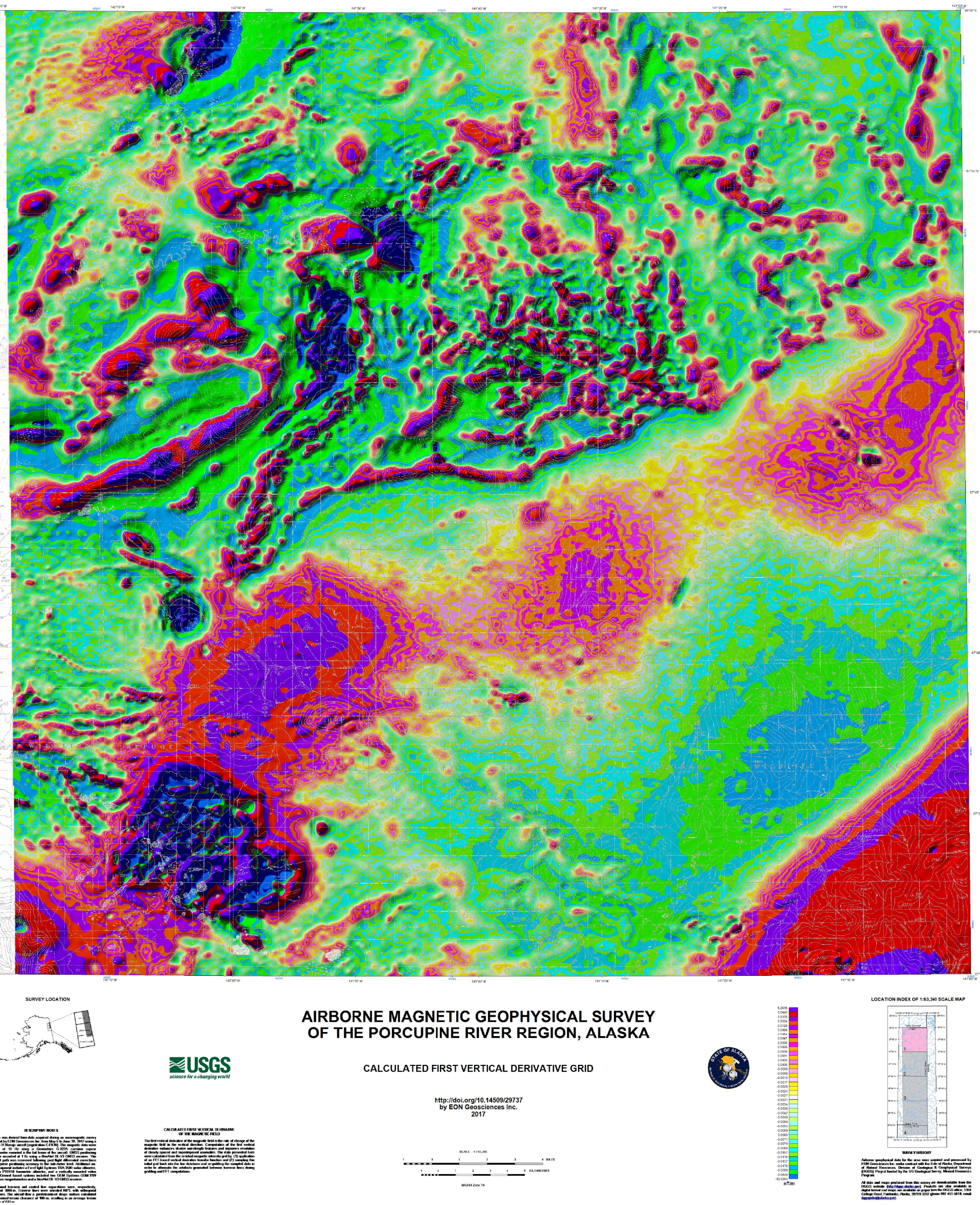




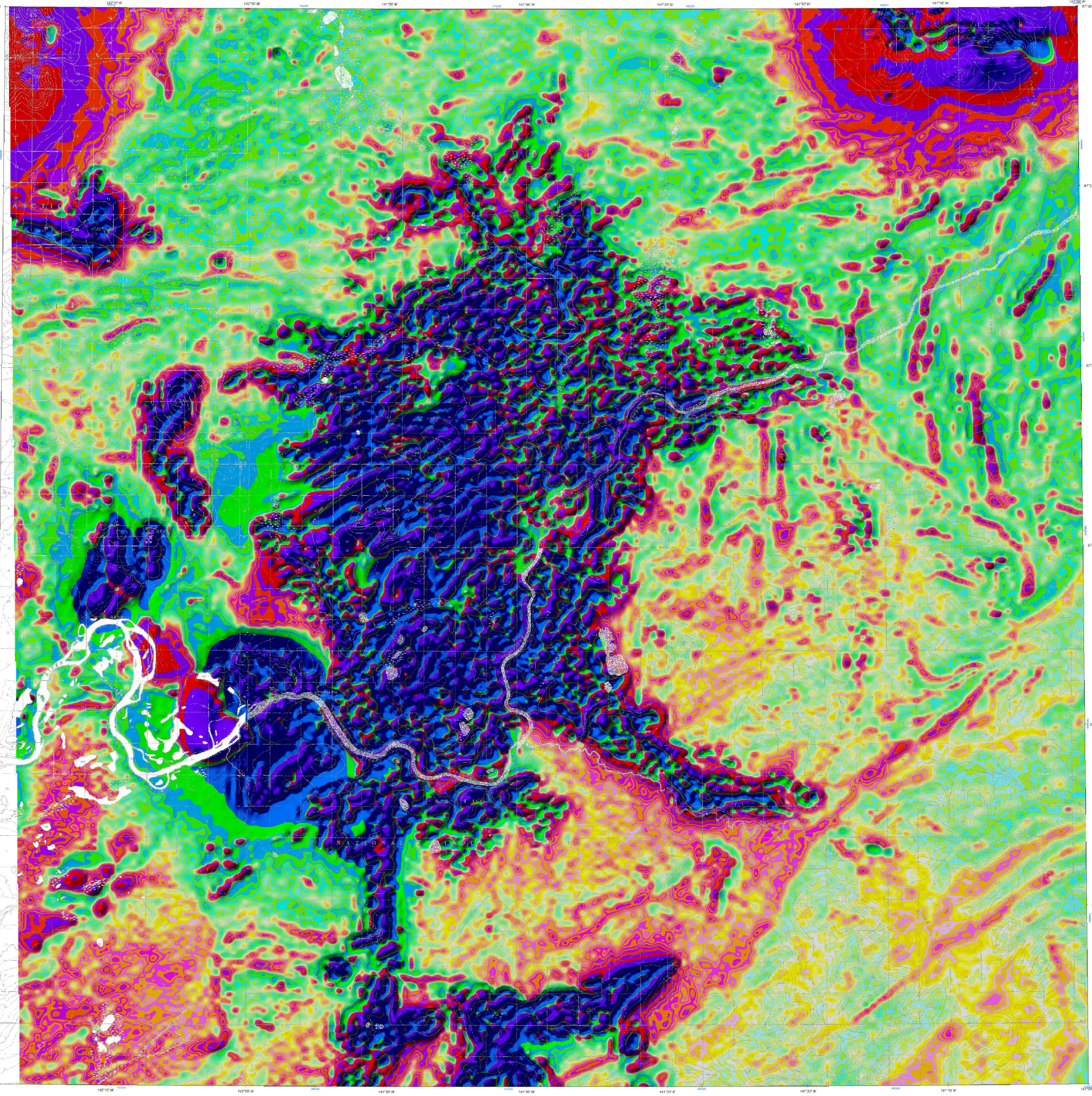

,

₹USGS
AIRBORNE MAGNETIC GEOPHYSICAL SURVEY

OF THE PORCUPINE RIVER REGION, ALASKA

CALCULATED FIRST VERTICAL DERIVATIVE GRID

http:://doi.org/10.14509/29737
by EON Geosciences Inc.
2017

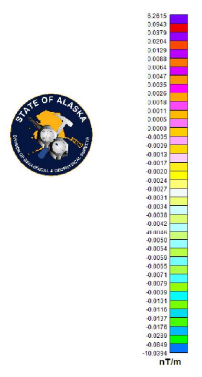

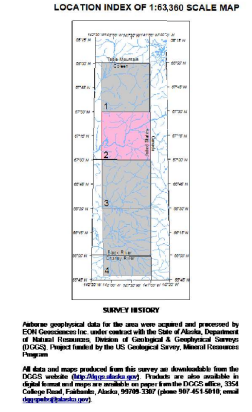

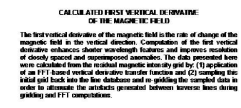

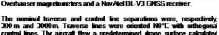

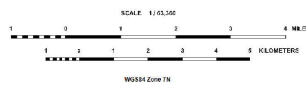




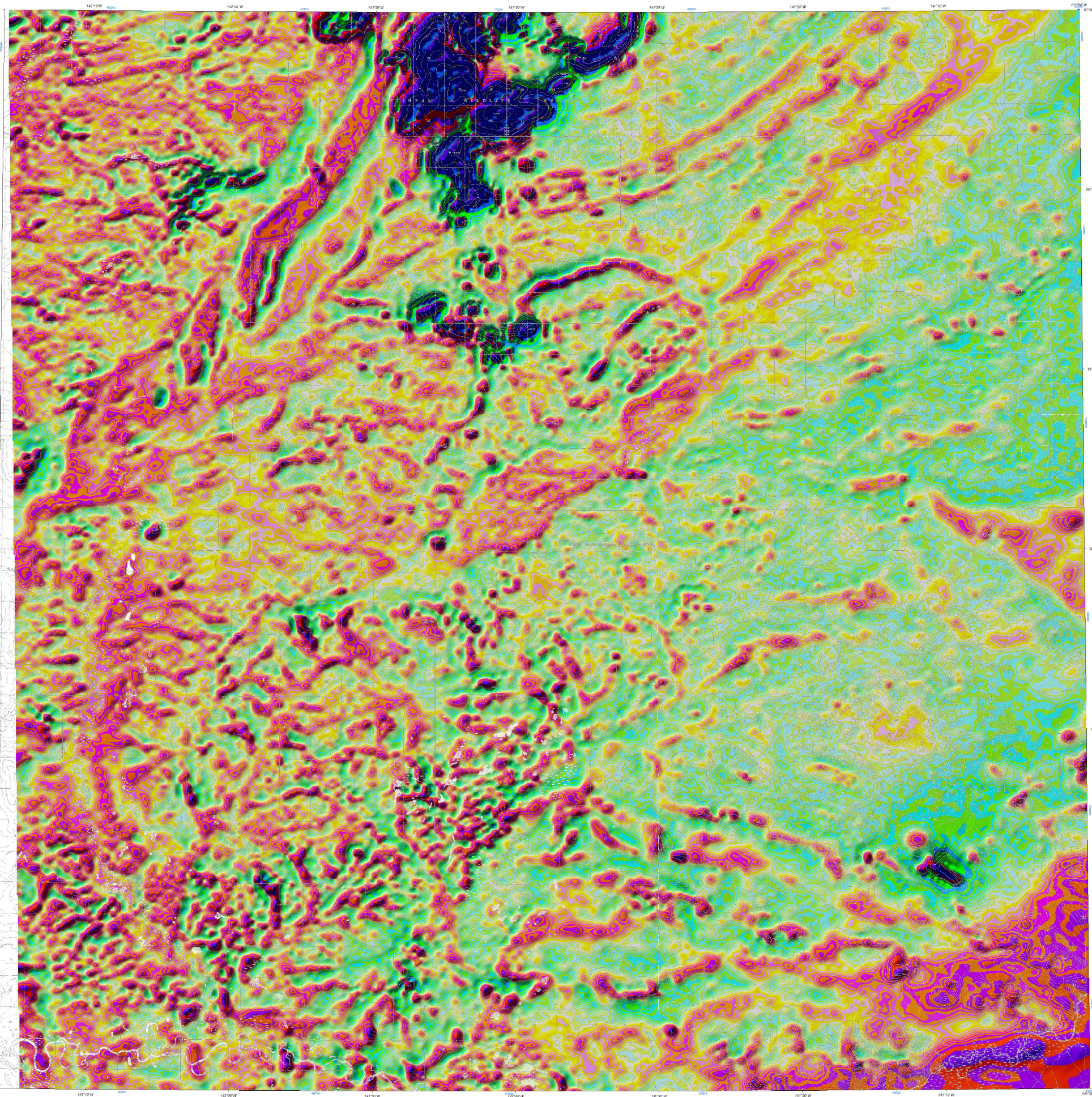<smiles>CC1CCC2CCCCC2C1</smiles>

₹USGS
AIRBORNE MAGNETIC GEOPHYSICAL SURVEY OF THE PORCUPINE RIVER REGION, ALASKA

CALCULATED FIRST VERTICAL DERIVATIVE GRID http:///doi.org/10.14509/29737
by EON Geosciences Inc.
2017
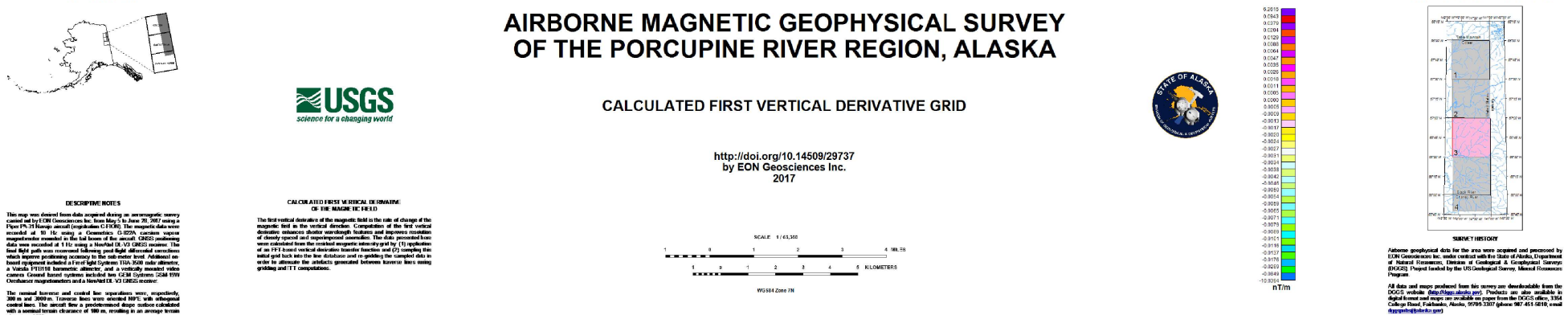


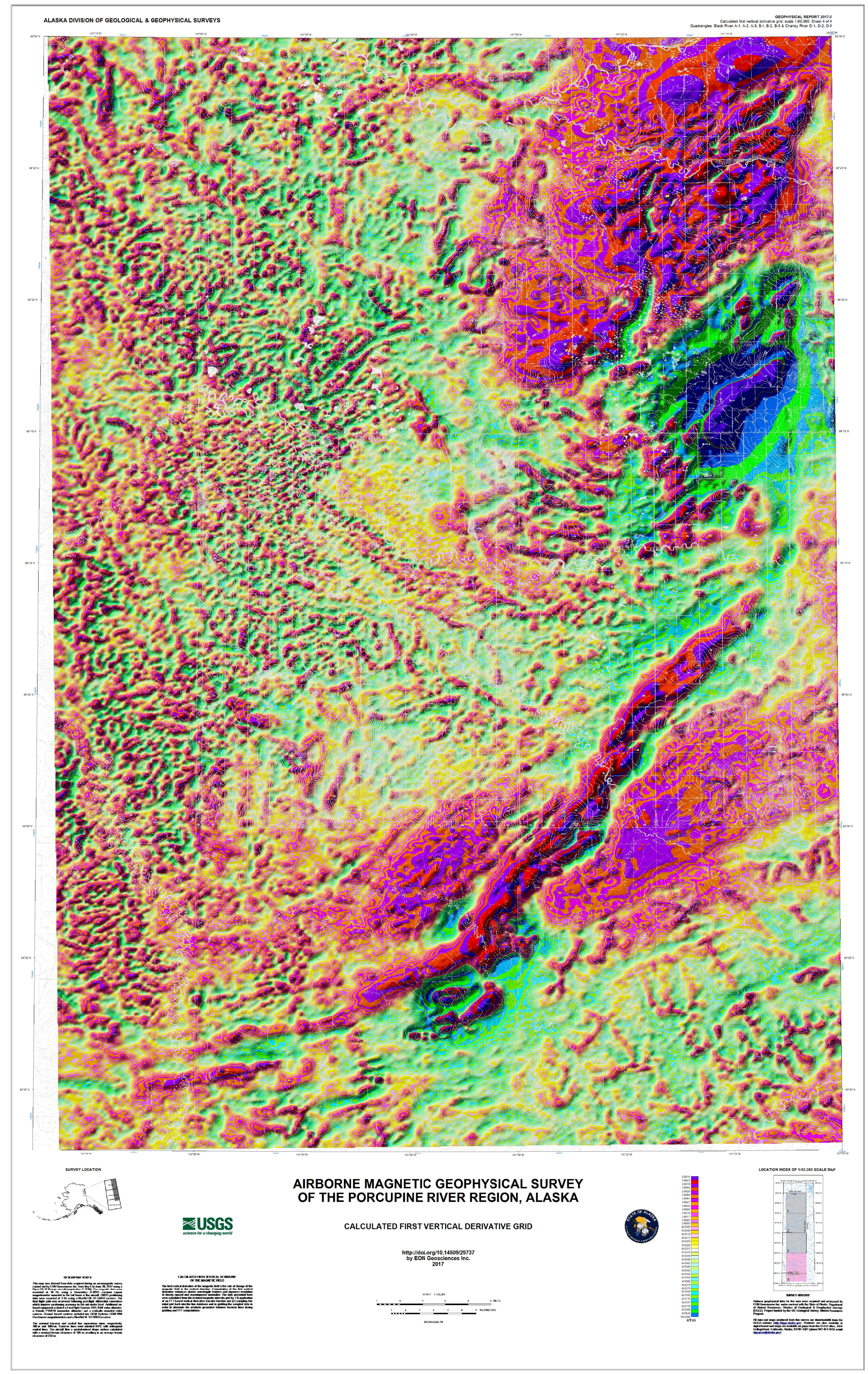




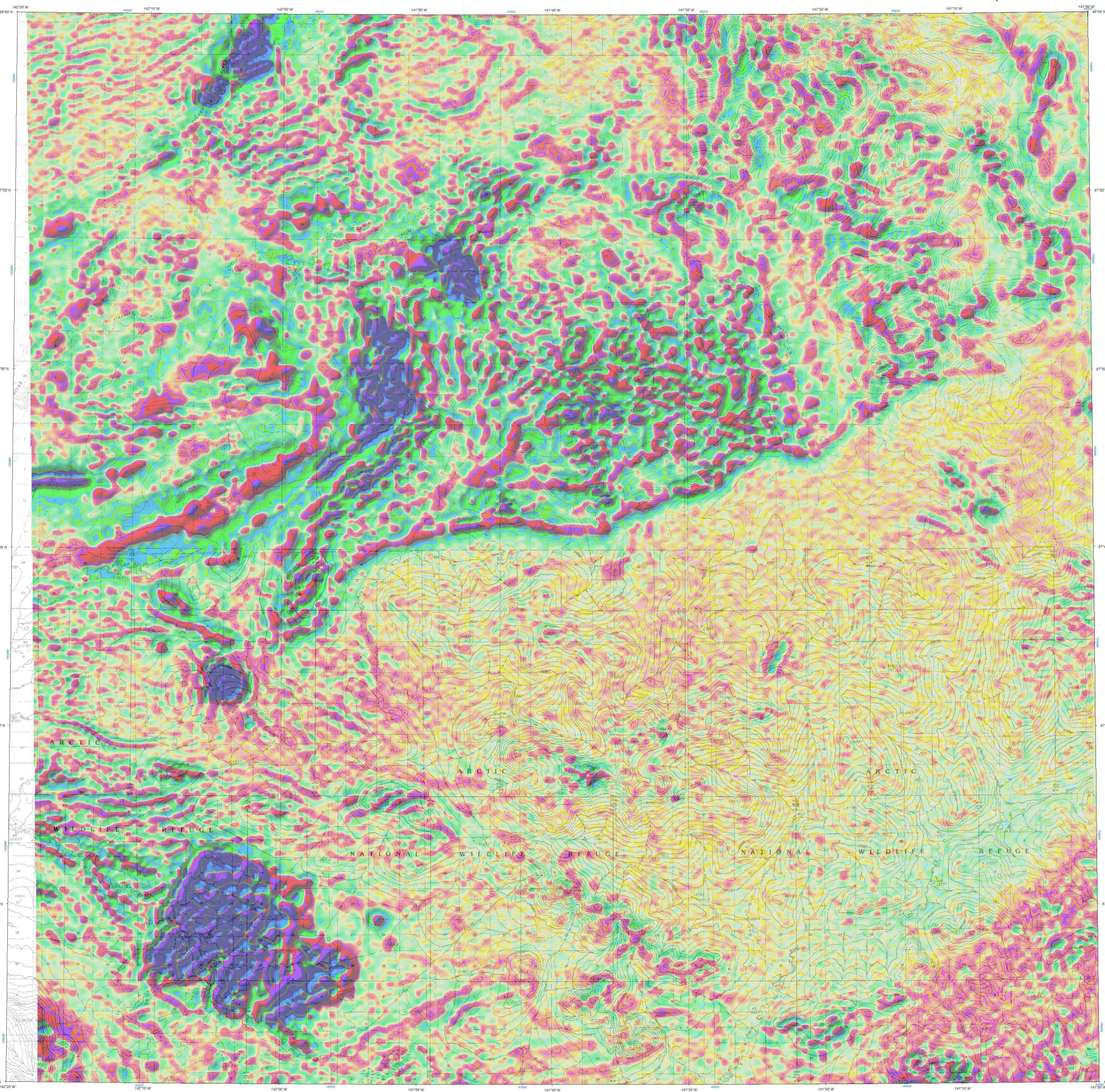

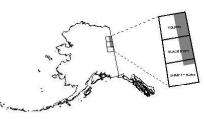

\section{₹USGS}

\section{AIRBORNE MAGNETIC GEOPHYSICAL SURVEY OF THE PORCUPINE RIVER REGION, ALASKA}

CALCULATED SECOND VERTICAL DERIVATIVE GRID
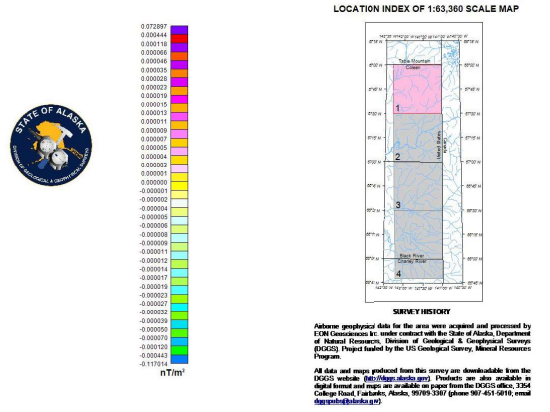

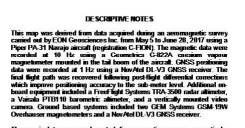

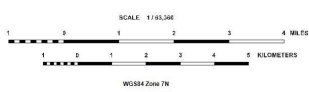




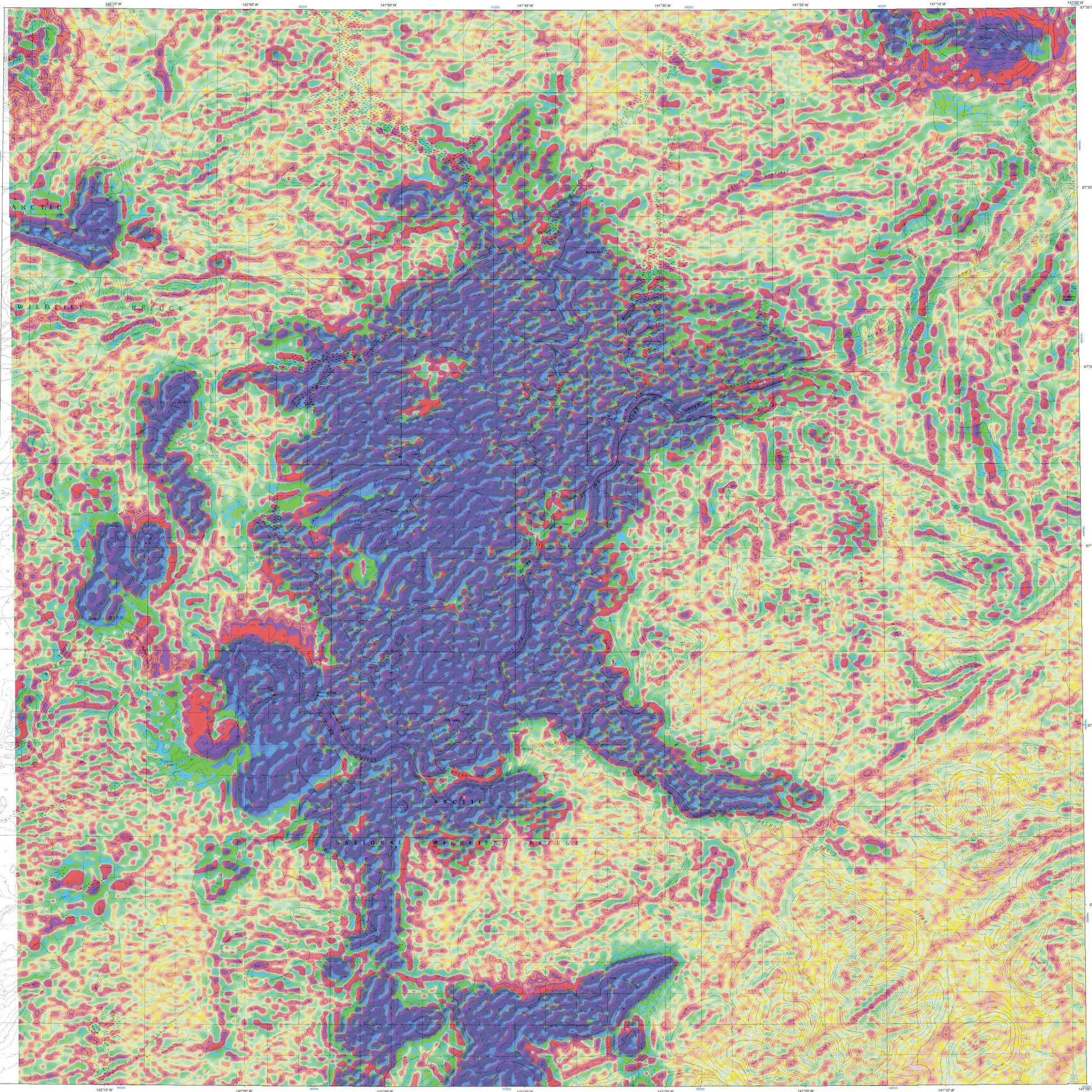

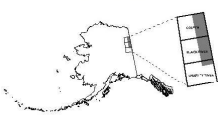

AIRBORNE MAGNETIC GEOPHYSICAL SURVEY
OF THE PORCUPINE RIVER REGION, ALASKA

\#USGS

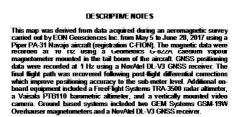

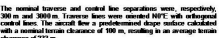

CALCULATED SECOND VERTICAL DERIVATIVE GRID

http:I//doi.org/10.14509/29737
by EON Geosciences Inc.

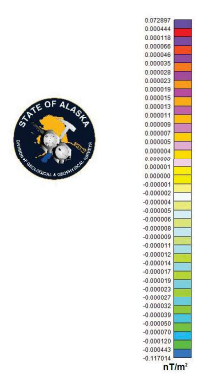

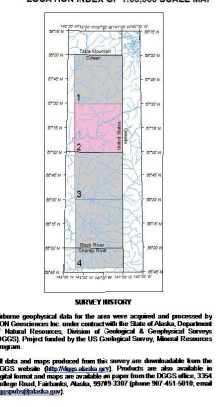




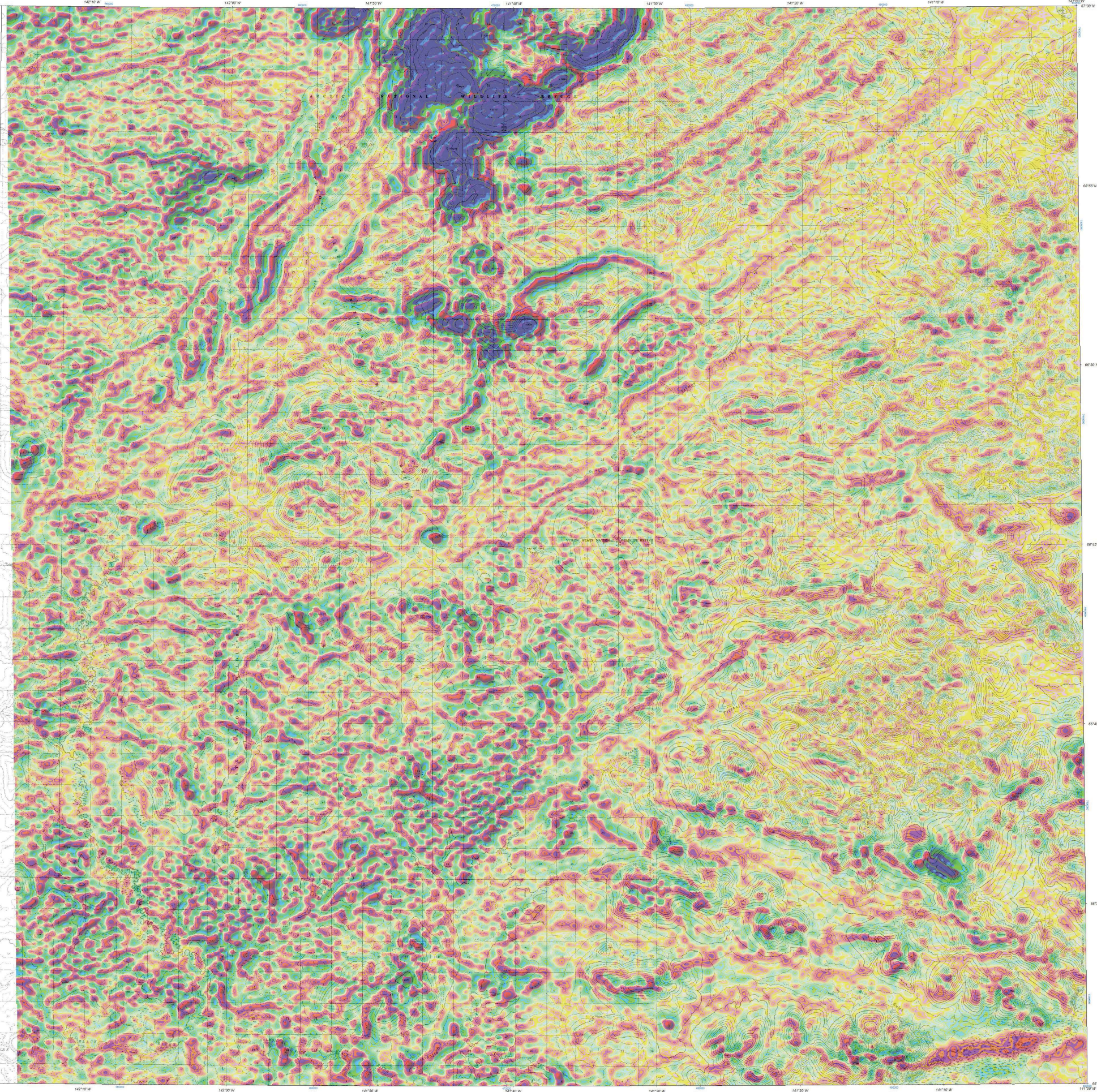

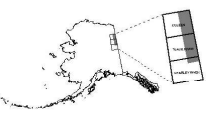

AIRBORNE MAGNETIC GEOPHYSICAL SURVEY
OF THE PORCUPINE RIVER REGION, ALASKA

₹USGS

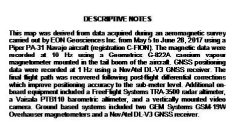

m $= \pm=-5=$
CALCULATED SECOND VERTICAL DERIVATIVE GRID

http:/ldoi.org/10.14509/29737
by EON Geosciences Inc.

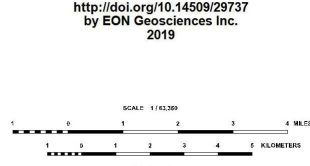

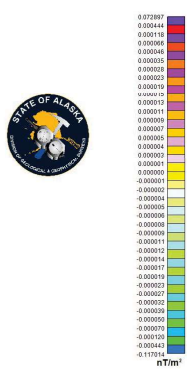

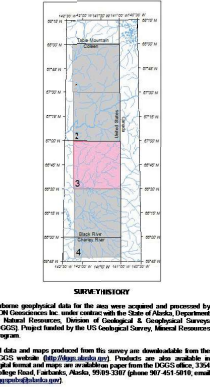




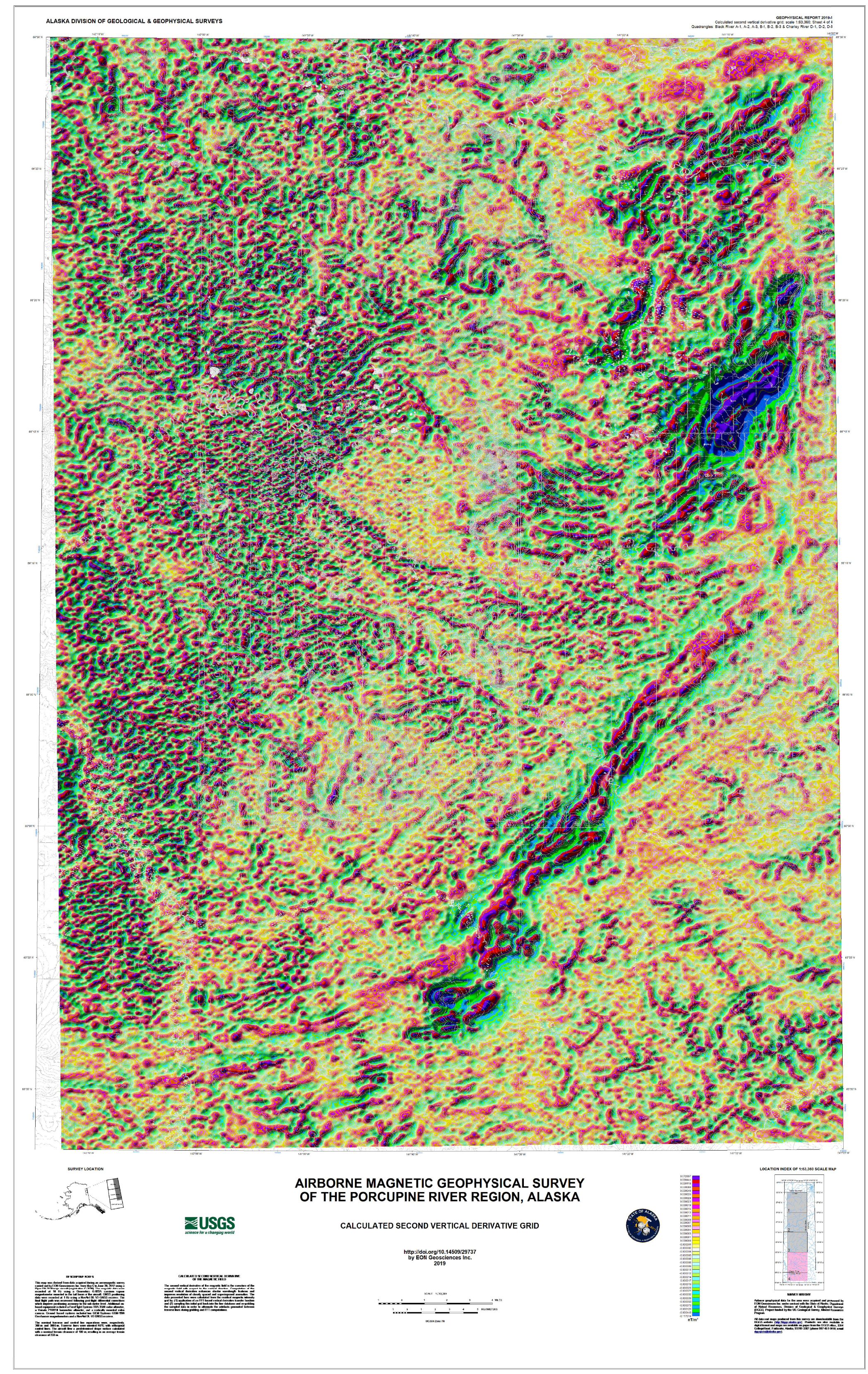




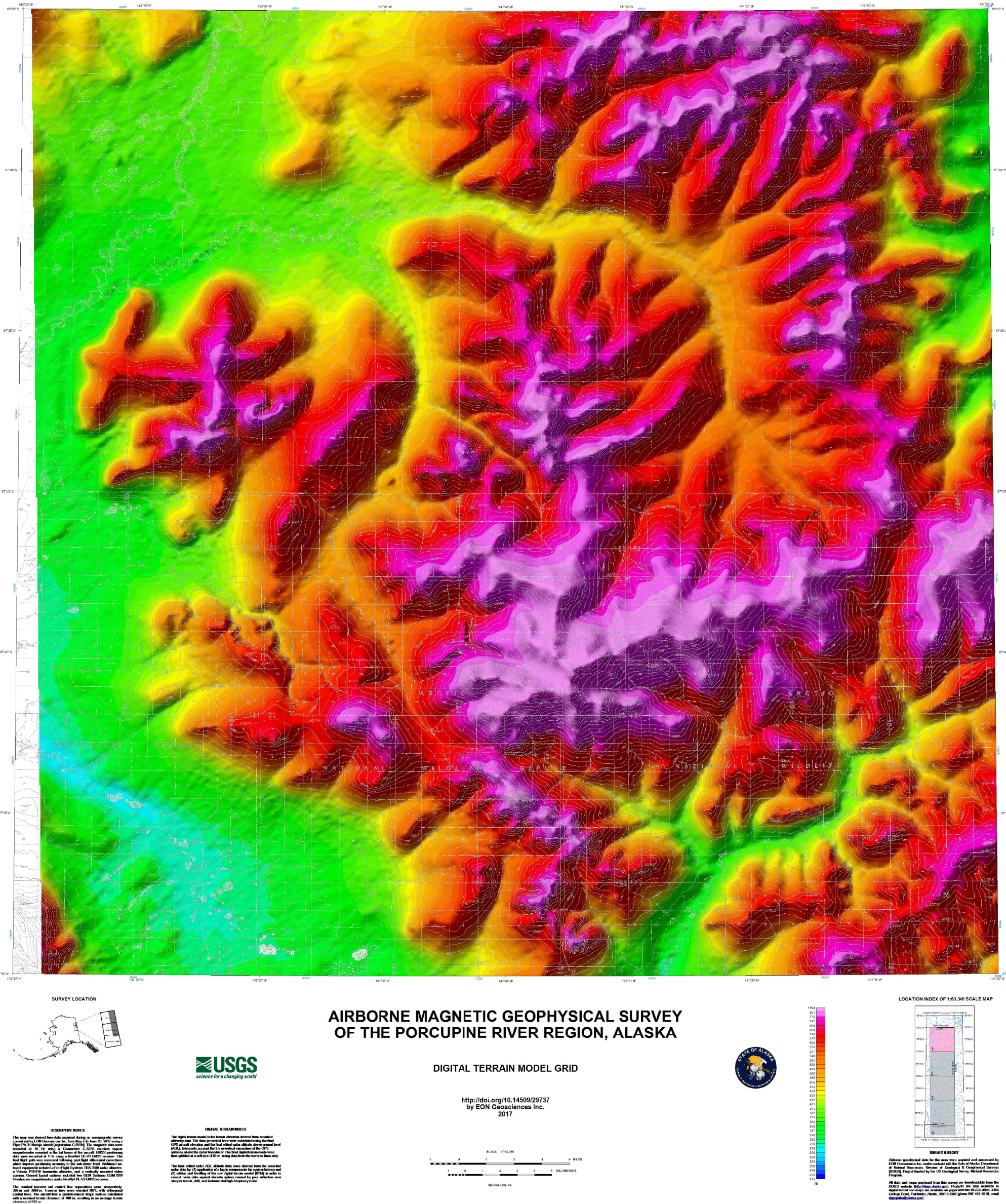




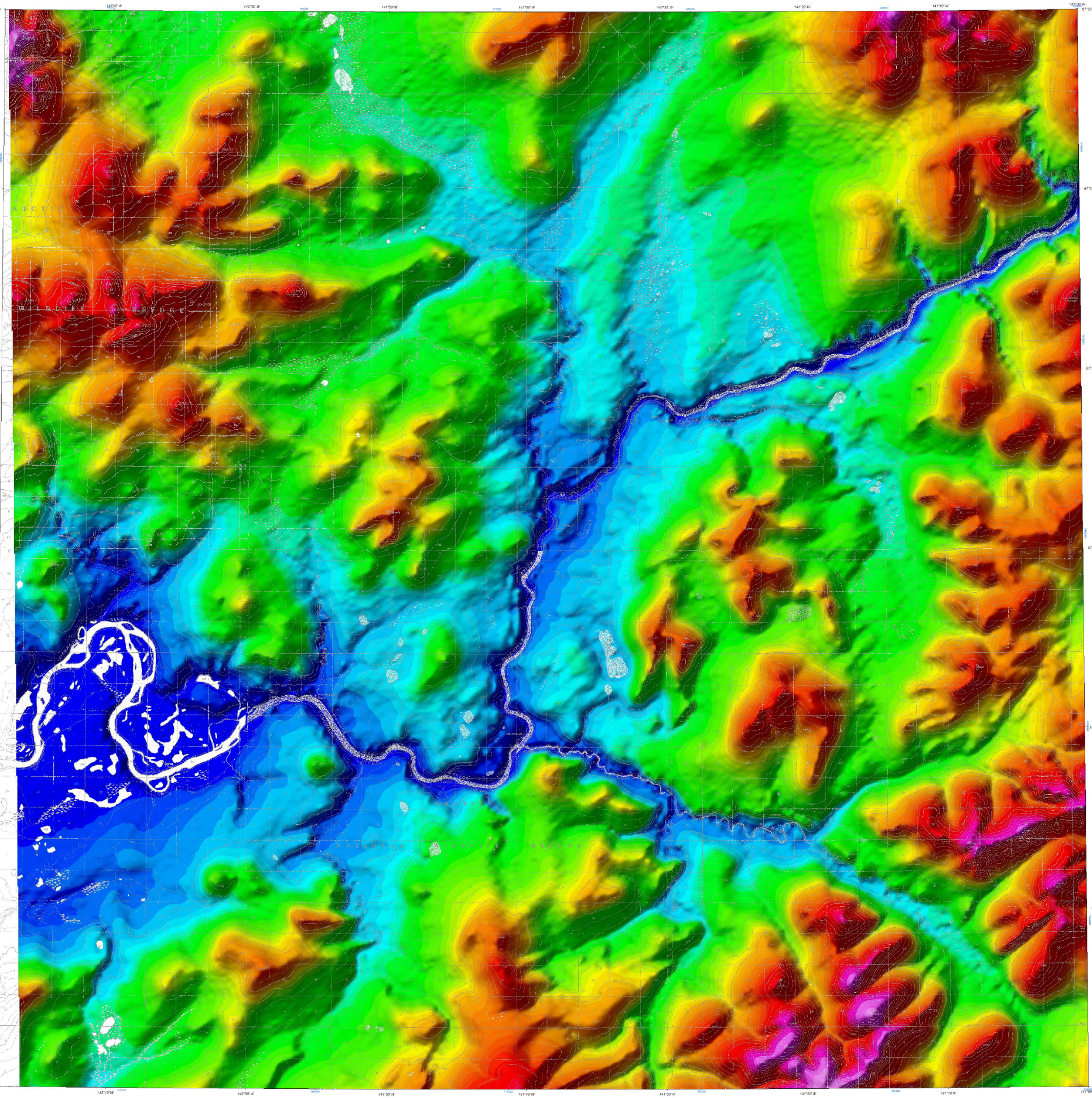

- $E$

₹USGS

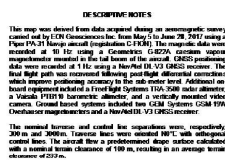

AIRBORNE MAGNETIC GEOPHYSICAL SURVEY OF THE PORCUPINE RIVER REGION, ALASKA

DIGITAL TERRAIN MODEL GRID

http://doi.org/10.14509/29737
by EON Geosciences Inc.
2017

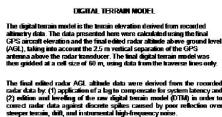

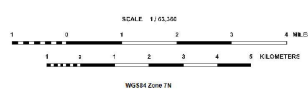

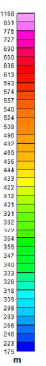

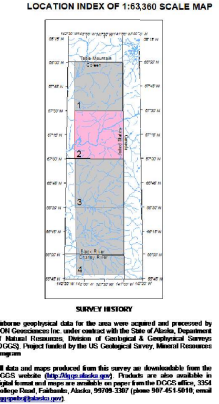




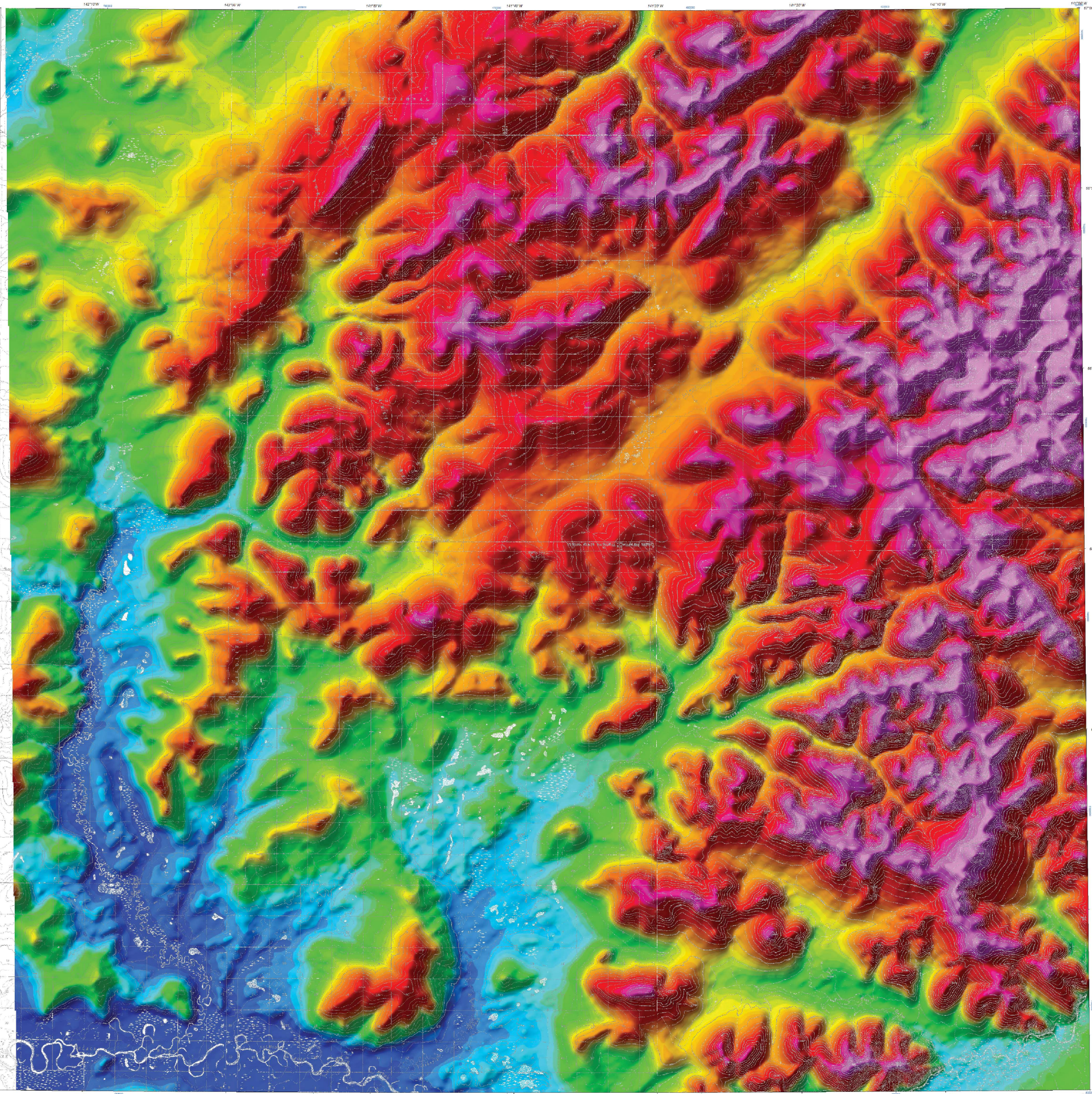

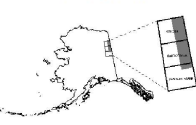

₹USGS

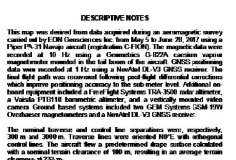

AIRBORNE MAGNETIC GEOPHYSICAL SURVEY

OF THE PORCUPINE RIVER REGION, ALASKA

DIGITAL TERRAIN MODEL GRID

http://doi.org/10.14509/29737
by EON Geosciences Inc.
2017

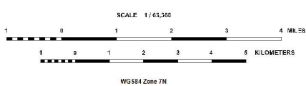

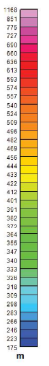




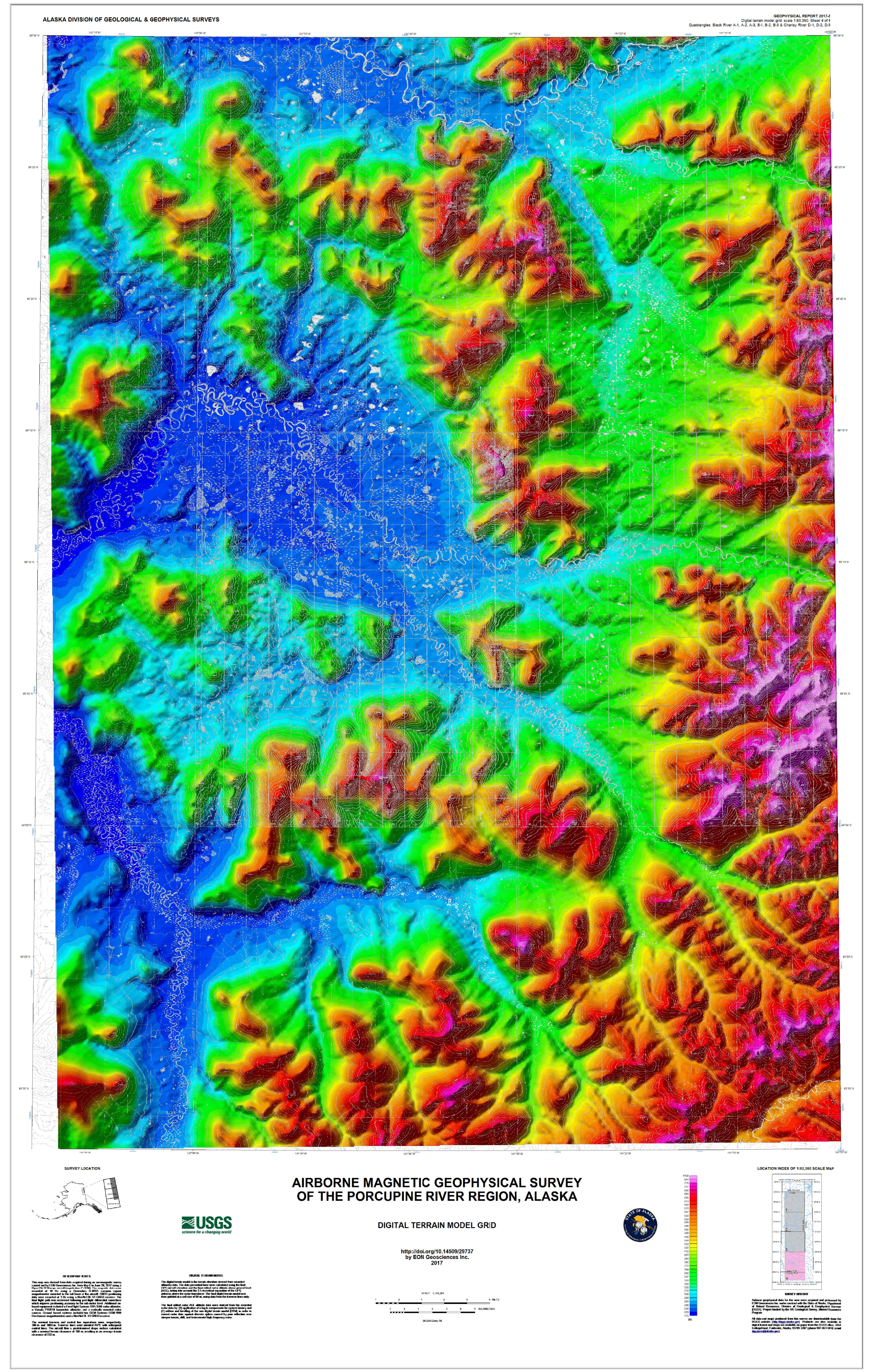




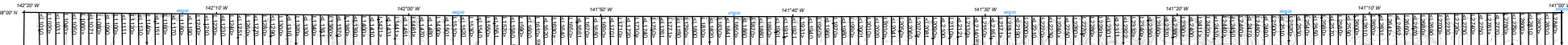

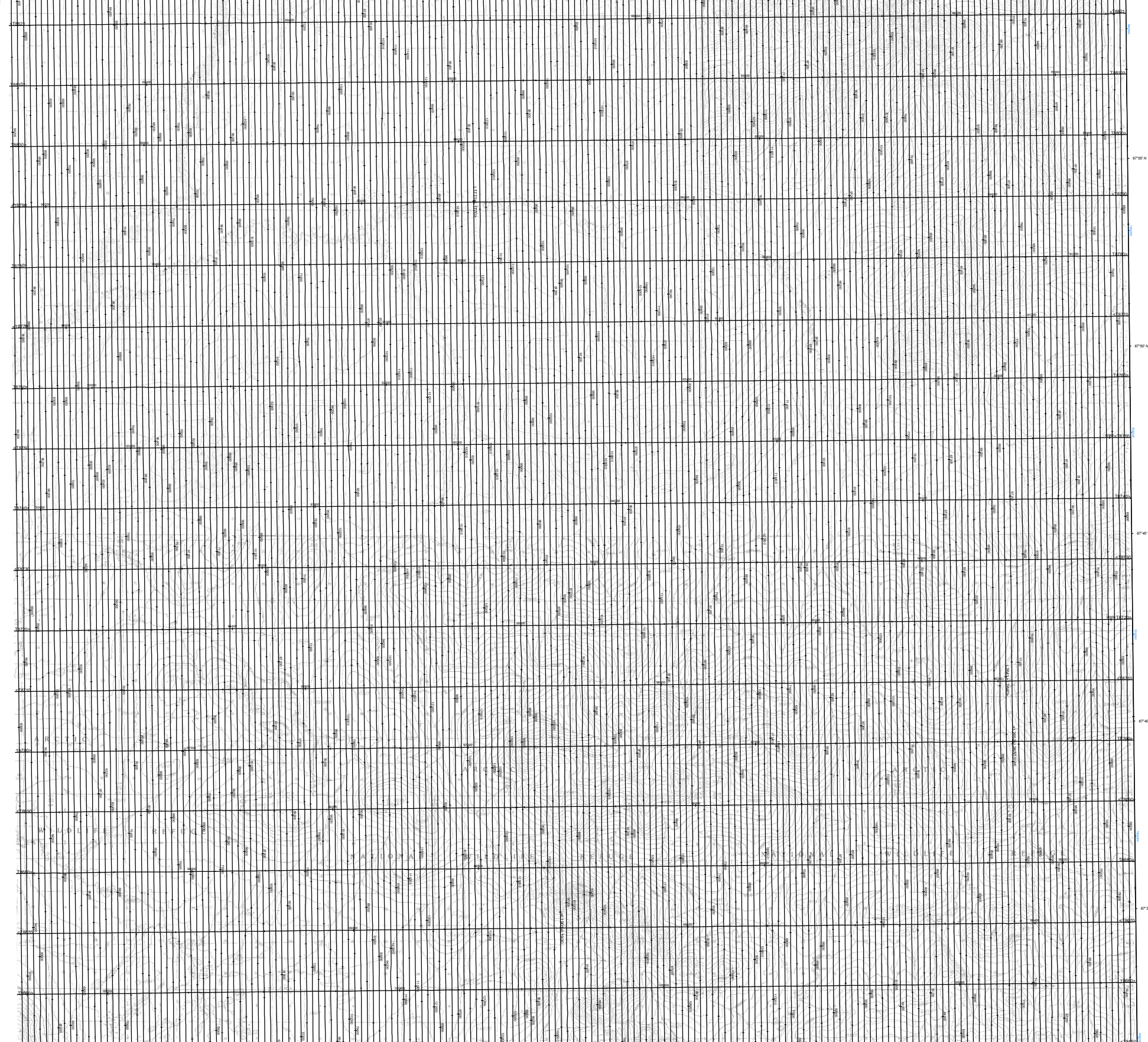
.

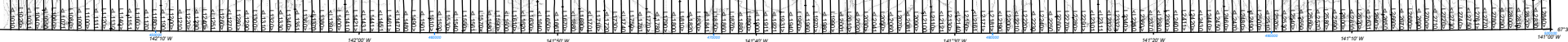

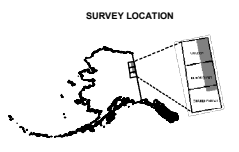

AIRBORNE MAGNETIC GEOPHYSICAL SURVEY OF THE PORCUPINE RIVER REGION, ALASKA

₹USGS
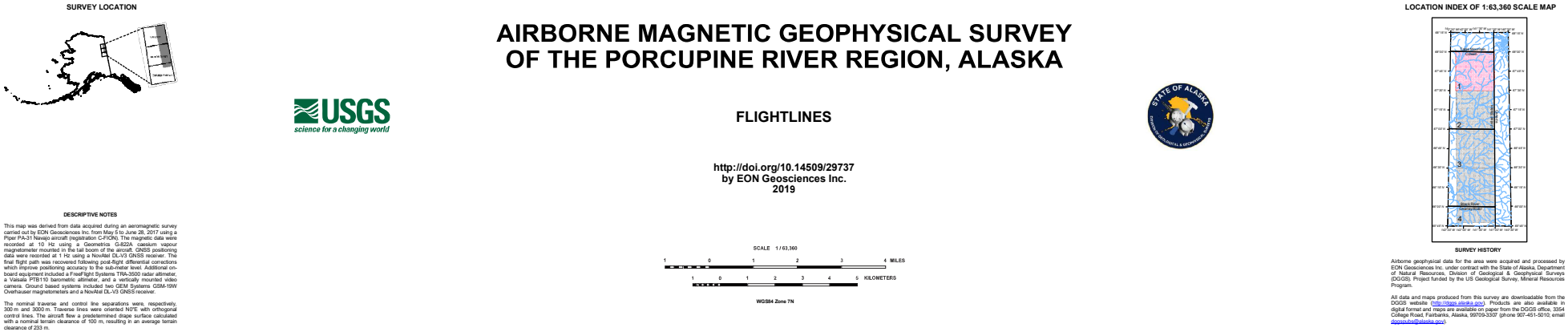


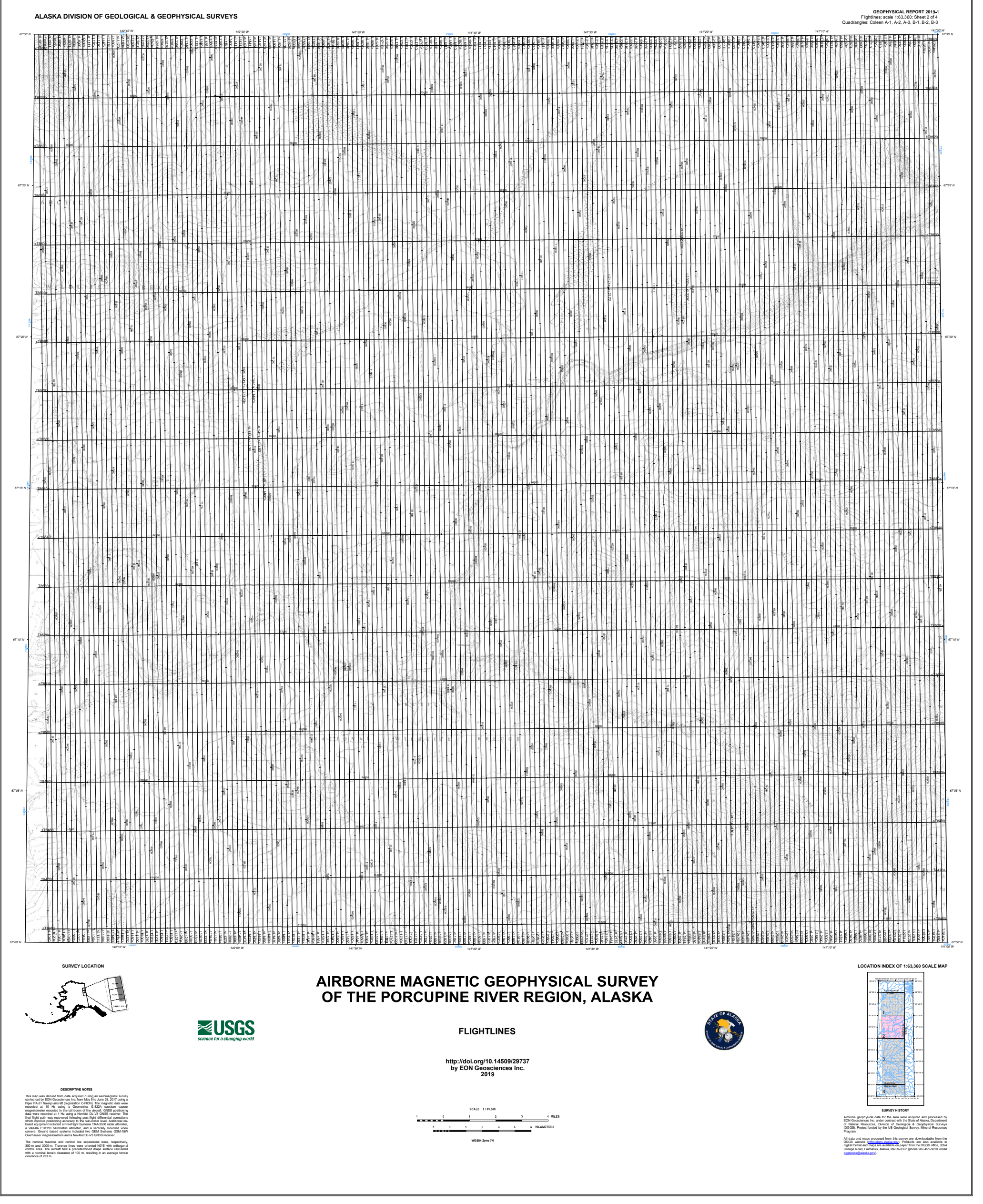




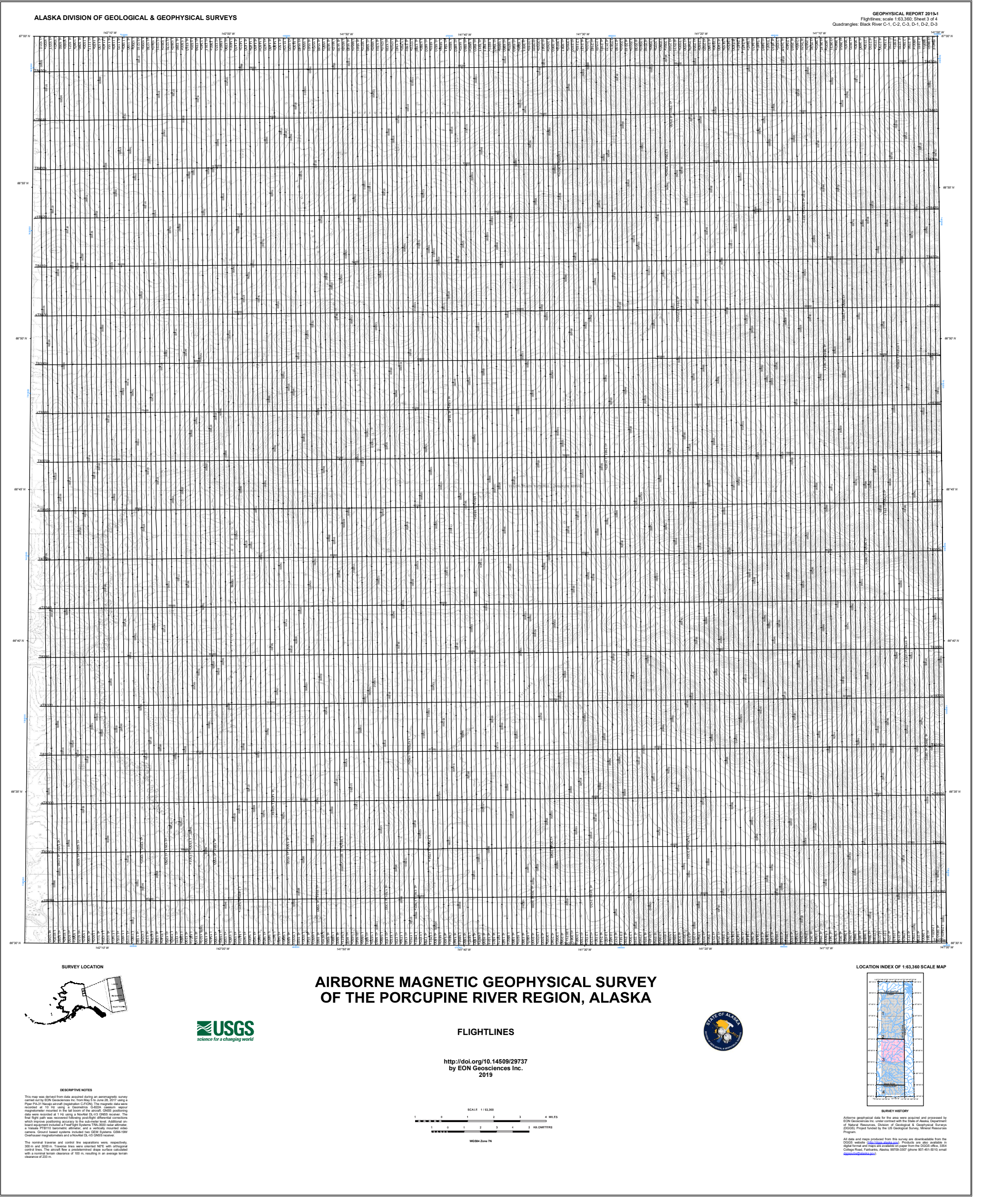




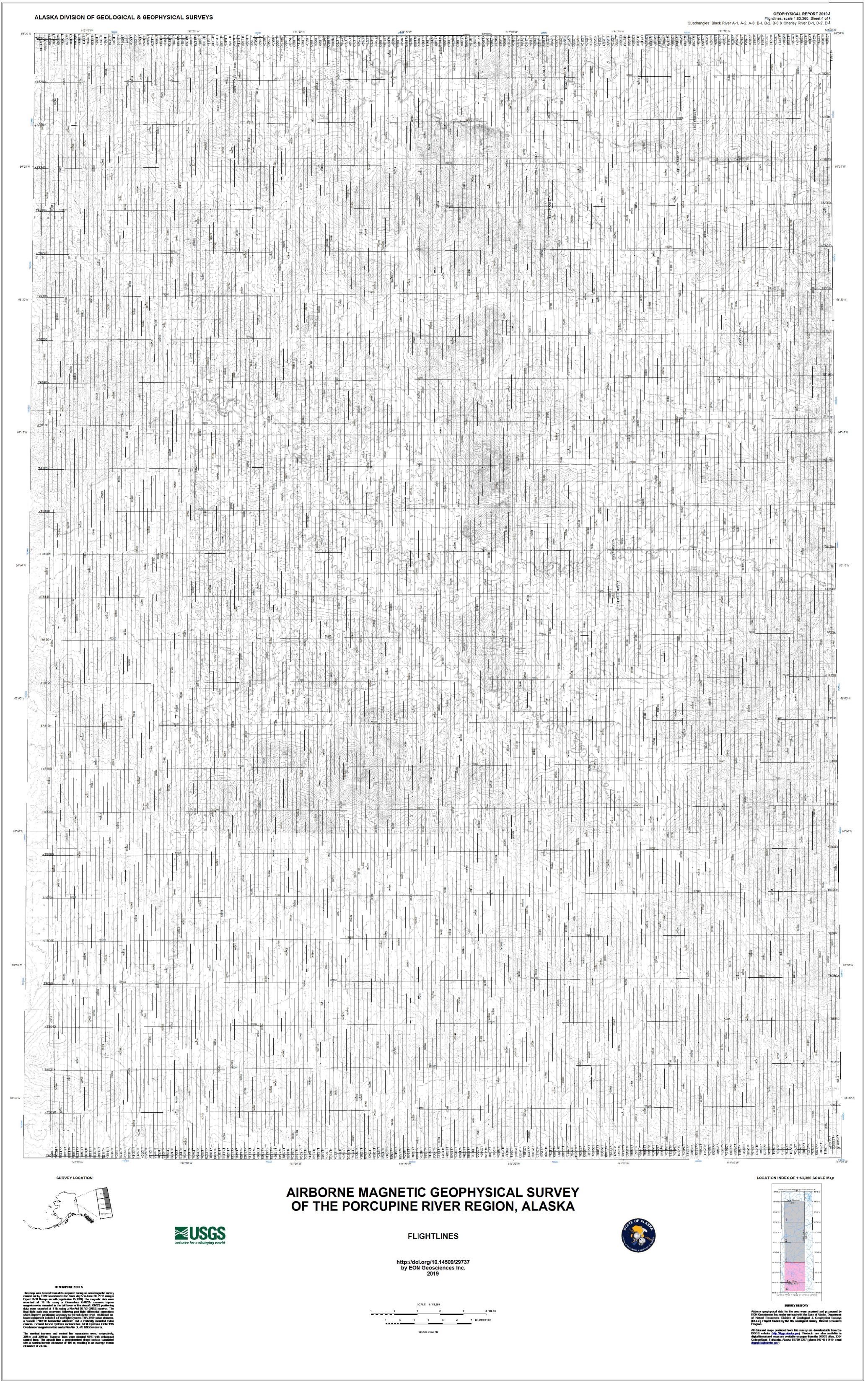




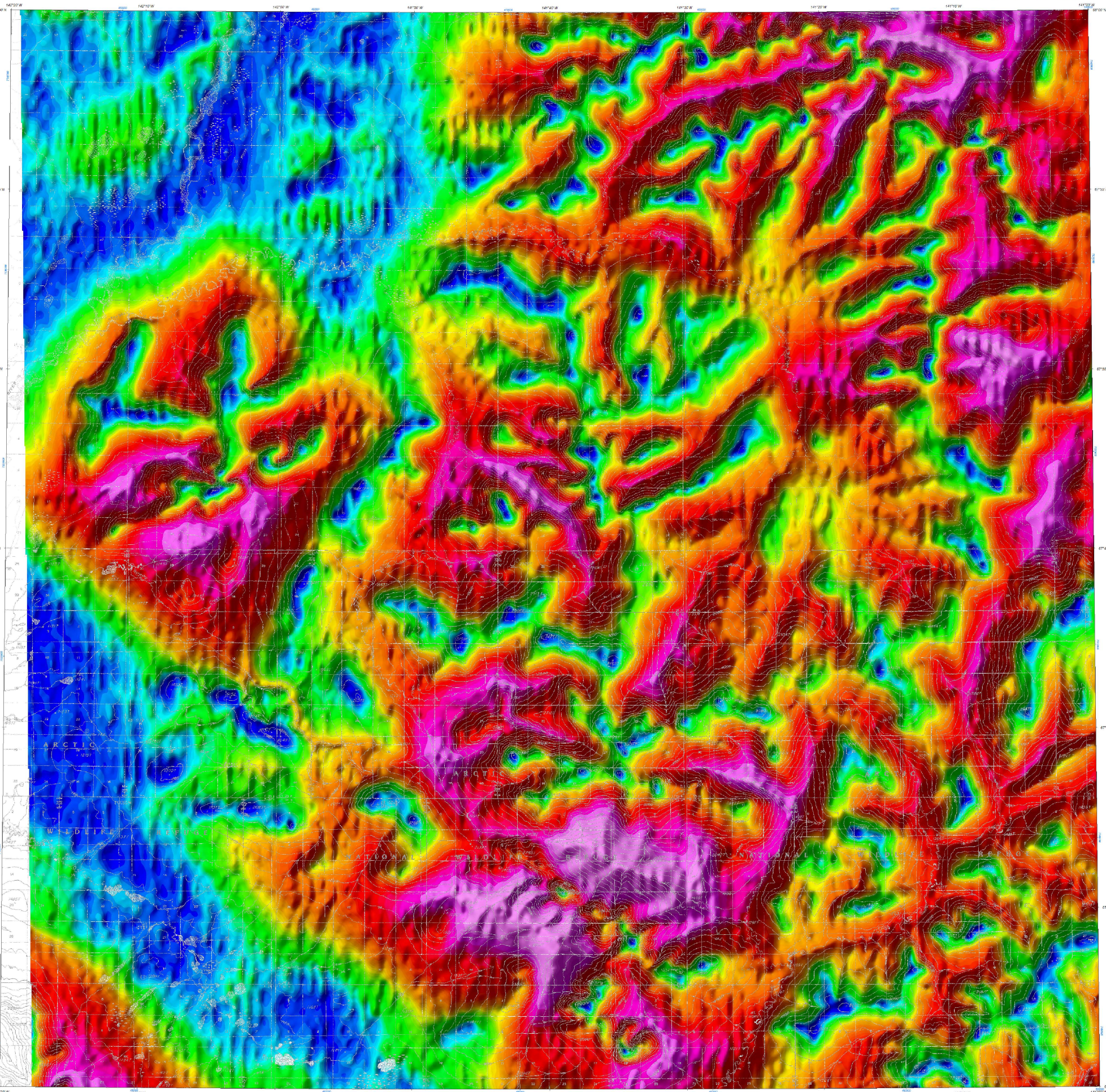

$\theta$

₹USGS
AIRBORNE MAGNETIC GEOPHYSICAL SURVEY OF THE PORCUPINE RIVER REGION, ALASKA

GROUND CLEARANCE GRID

http://doi.org/10.14509/29737
by EON Geosciences Inc.

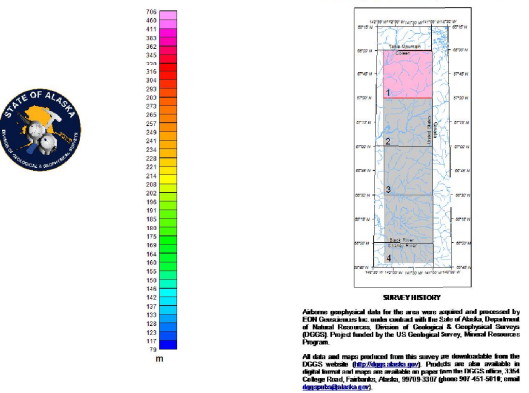




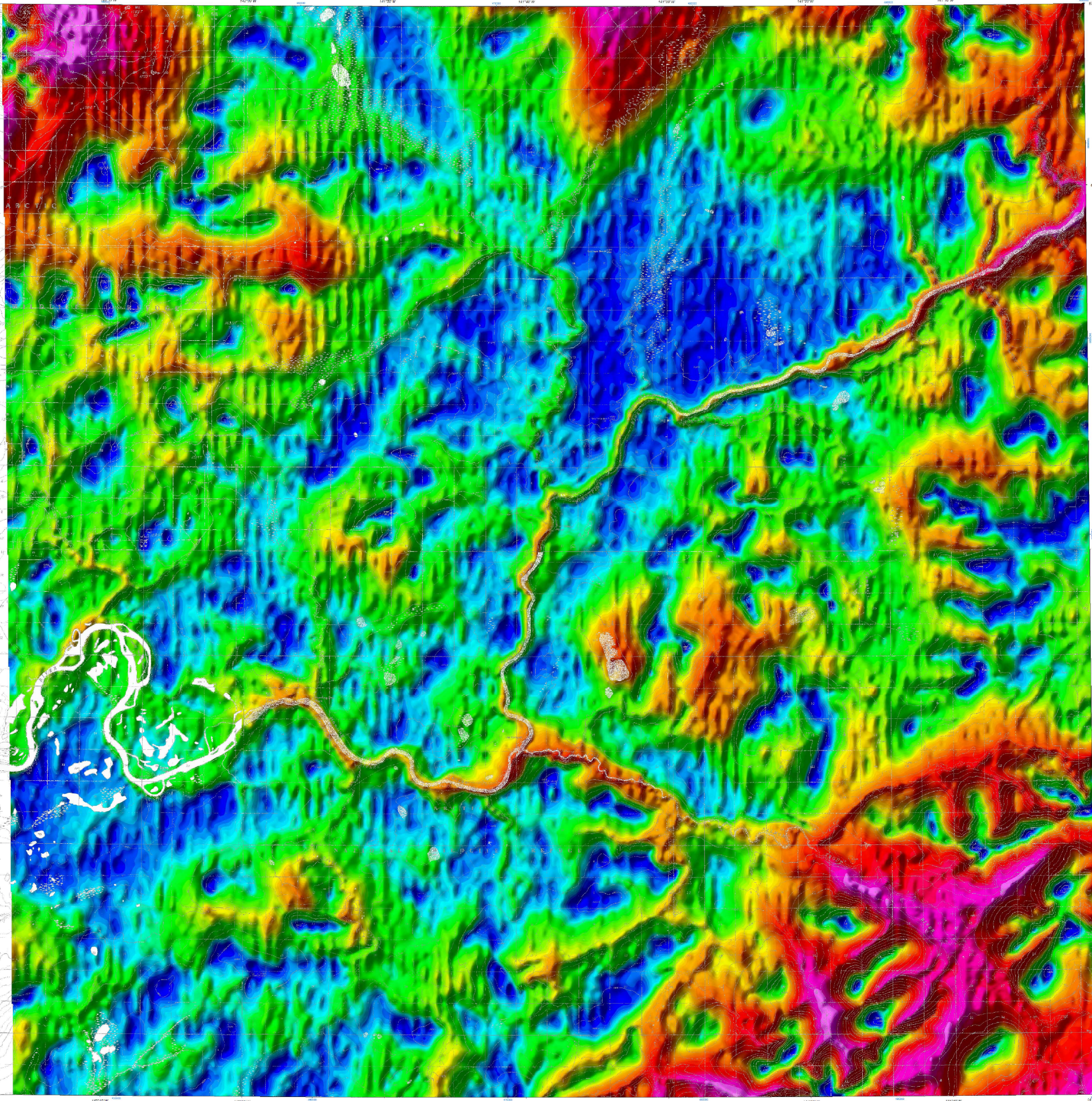

$\rightarrow$ 目

₹USGS
AIRBORNE MAGNETIC GEOPHYSICAL SURVEY OF THE PORCUPINE RIVER REGION, ALASKA

GROUND CLEARANCE GRID

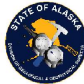

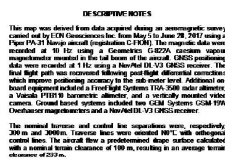

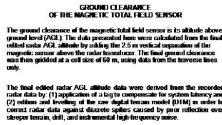

http:I/doi.org/10014509/29737
by EON Geosciences Inc.
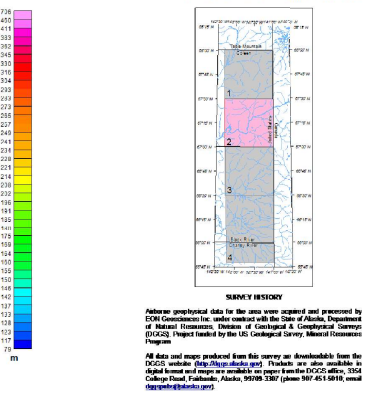


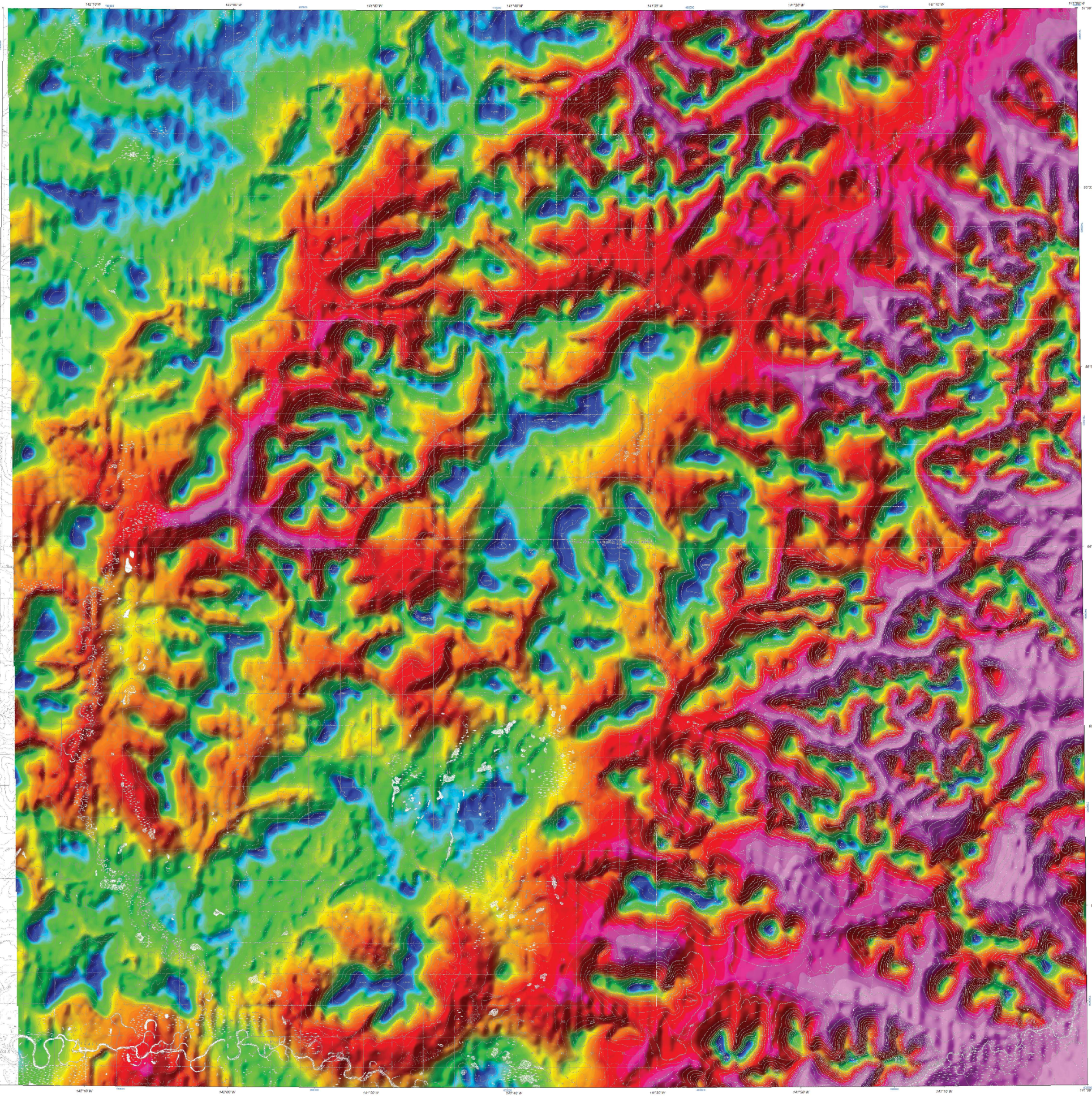

且田

₹USGS
AIRBORNE MAGNETIC GEOPHYSICAL SURVEY OF THE PORCUPINE RIVER REGION, ALASKA

GROUND CLEARANCE GRID

http:///doi.org/10.14509/29737
by EON Geosciences Inc.

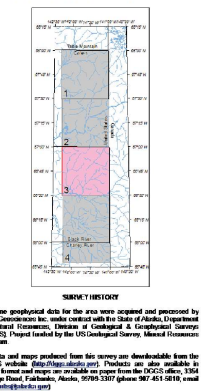




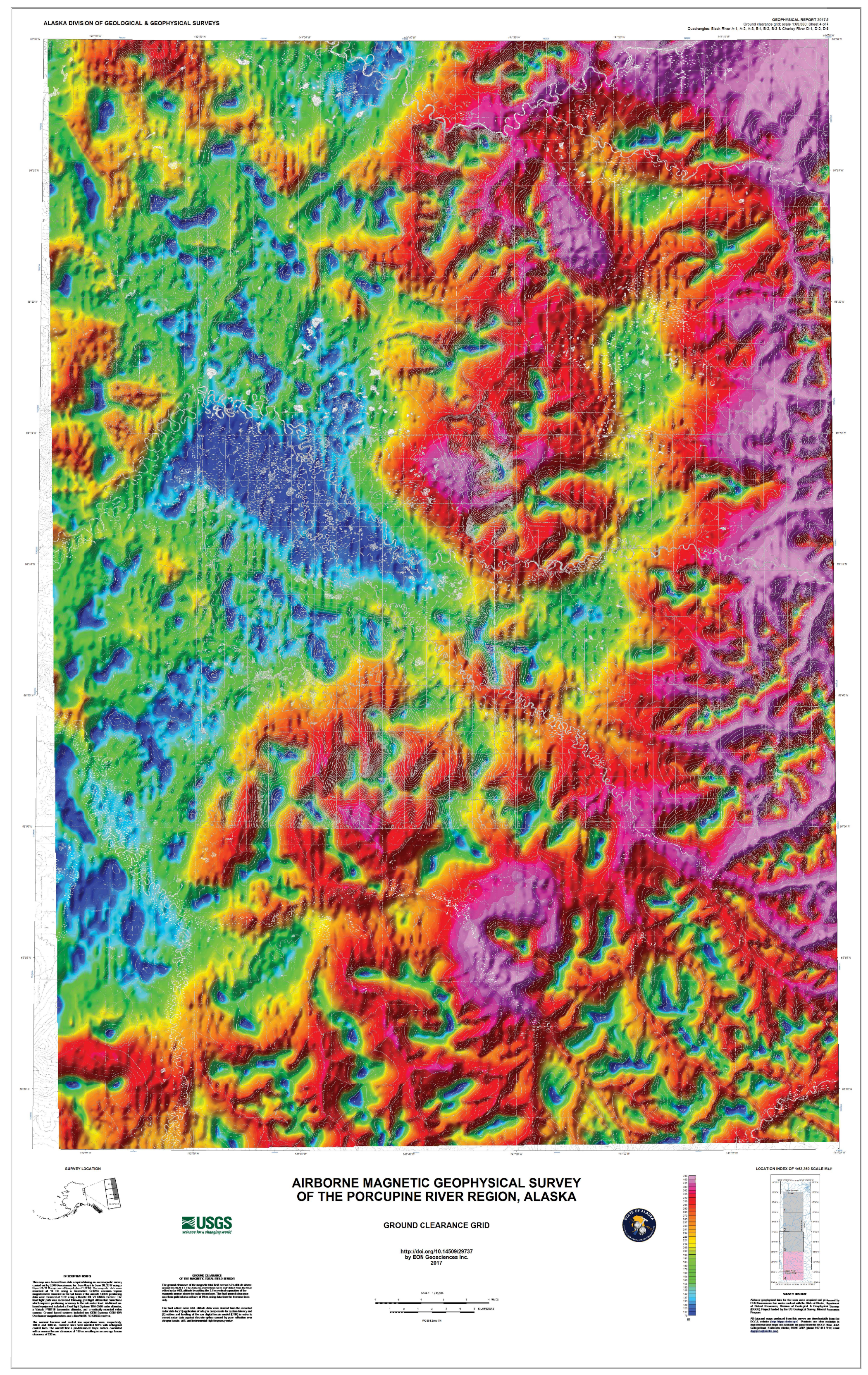



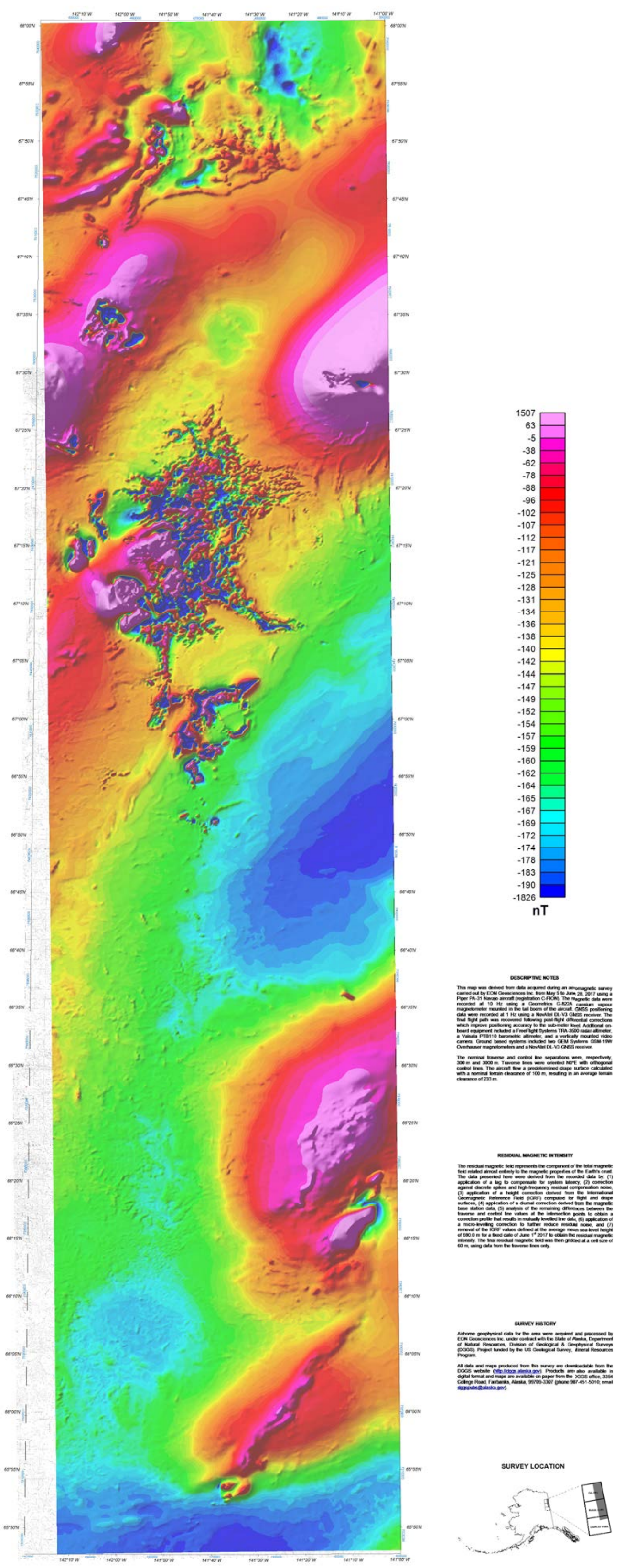

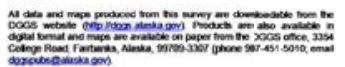

AIRBORNE MAGNETIC GEOPHYSICAL SURVEY OF THE PORCUPINE RIVER REGION, ALASKA

RESIDUAL MAGNETIC INTENSITY GRID

http:I//doi.org/10.14509/29737
by EON Geosciences Inc.
2019
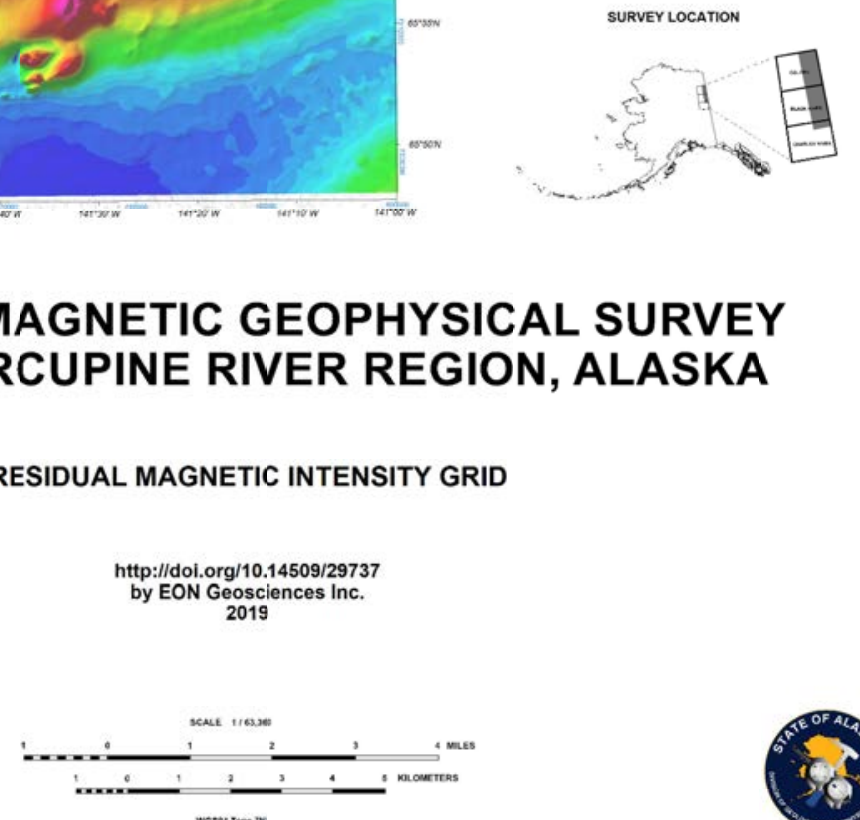


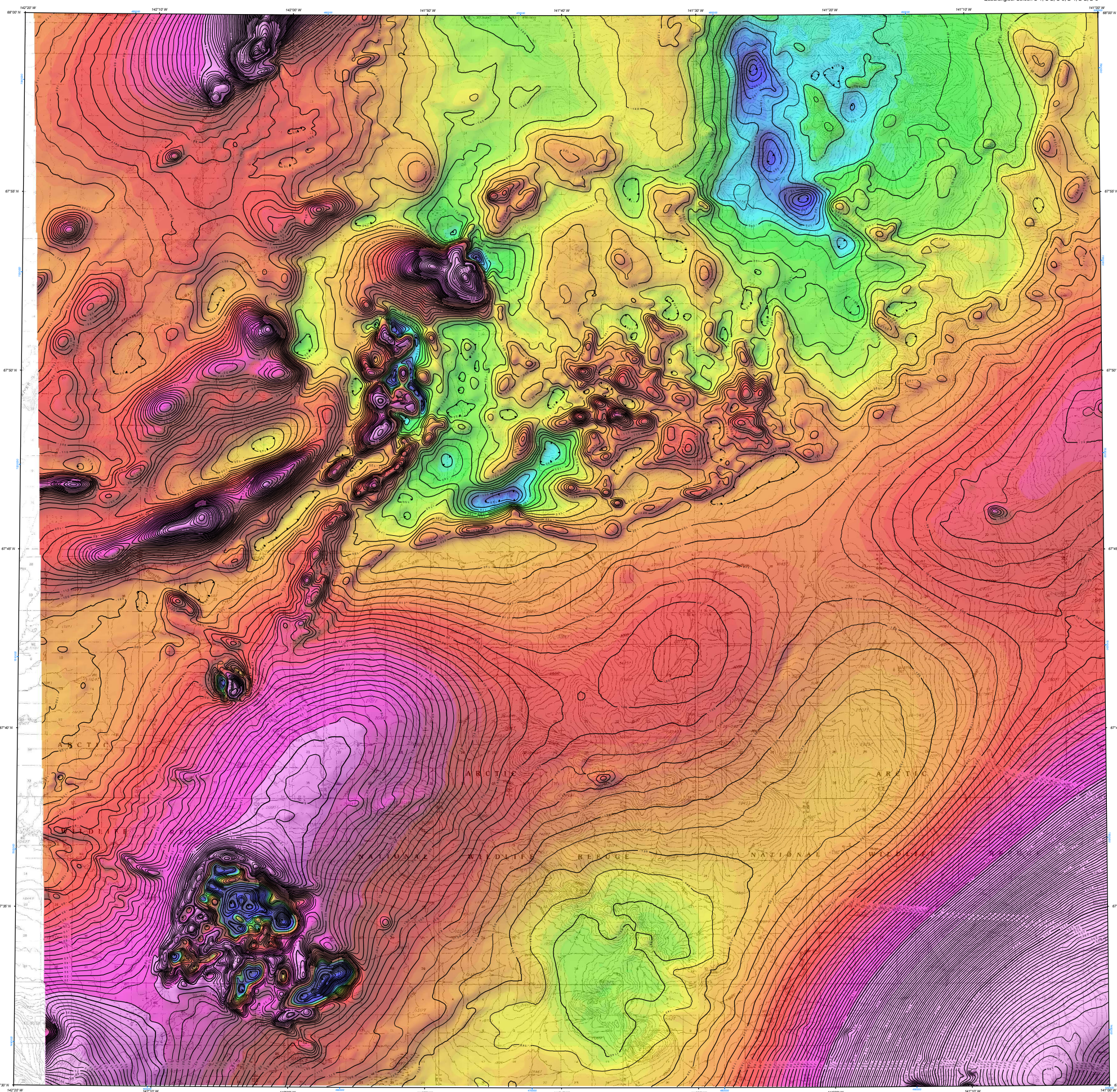

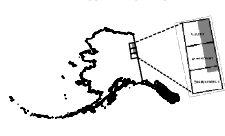

\section{AIRBORNE MAGNETIC GEOPHYSICAL SURVEY OF THE PORCUPINE RIVER REGION, ALASKA}

ॠUSGS
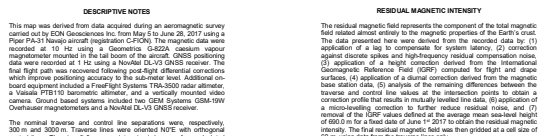

RESIDUAL MAGNETIC INTENSITY GRID AND CONTOURS

http://doi.org/10.14509/29737
by EON Geosciences Inc.
2019

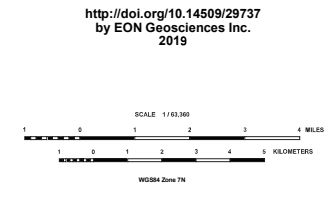

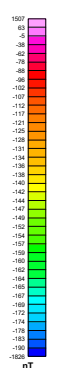

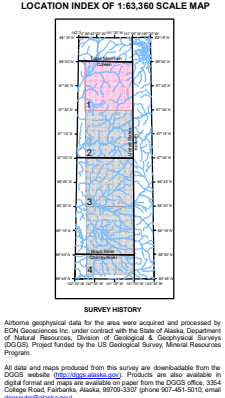




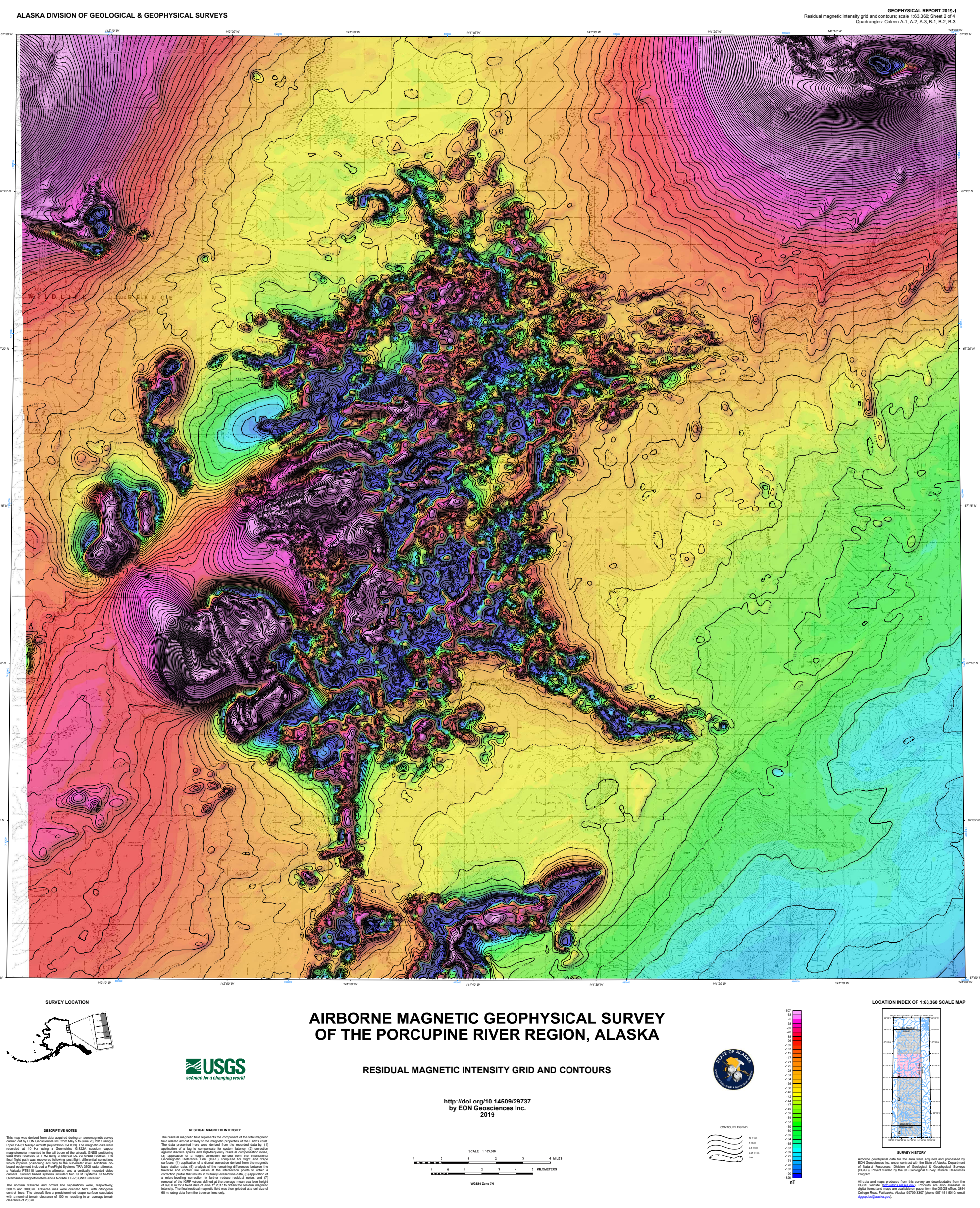



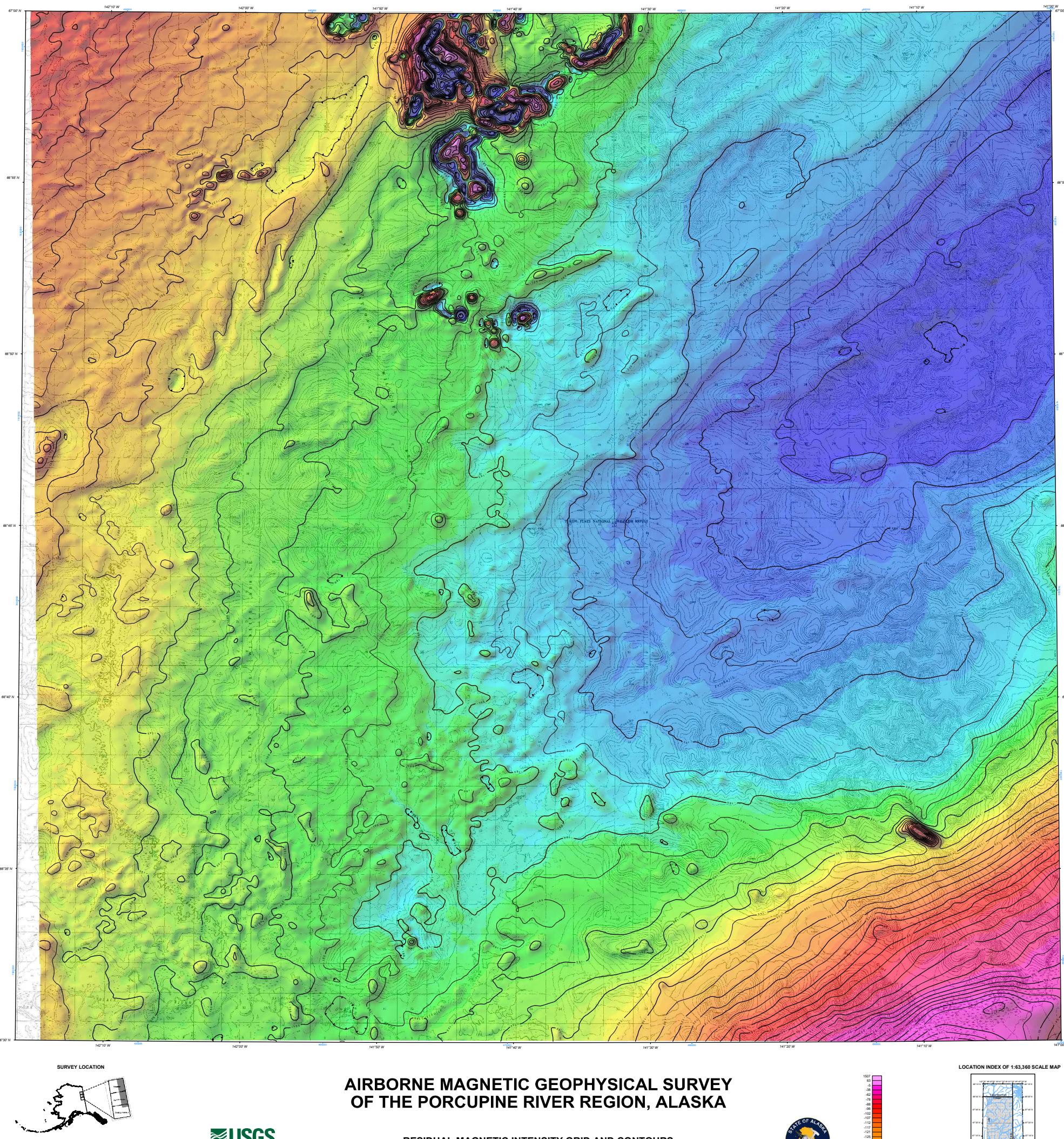

AIRBORNE MAGNETIC GEOPHYSICAL SURVEY OF THE PORCUPINE RIVER REGION, ALASKA

₹USGS

RESIDUAL MAGNETIC INTENSITY GRID AND CONTOURS
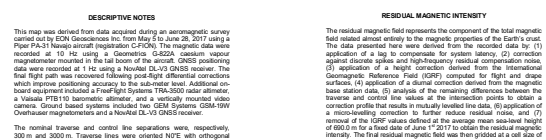

http://doi.org/10.14509/29737.
by EoN Geosciences Inc.
2019

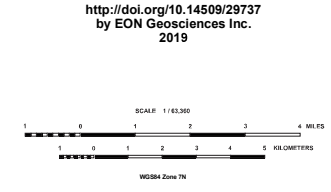

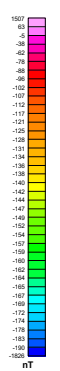

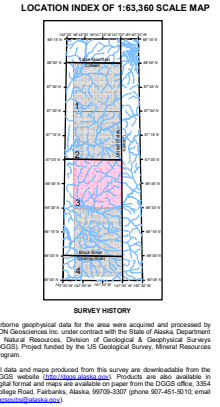




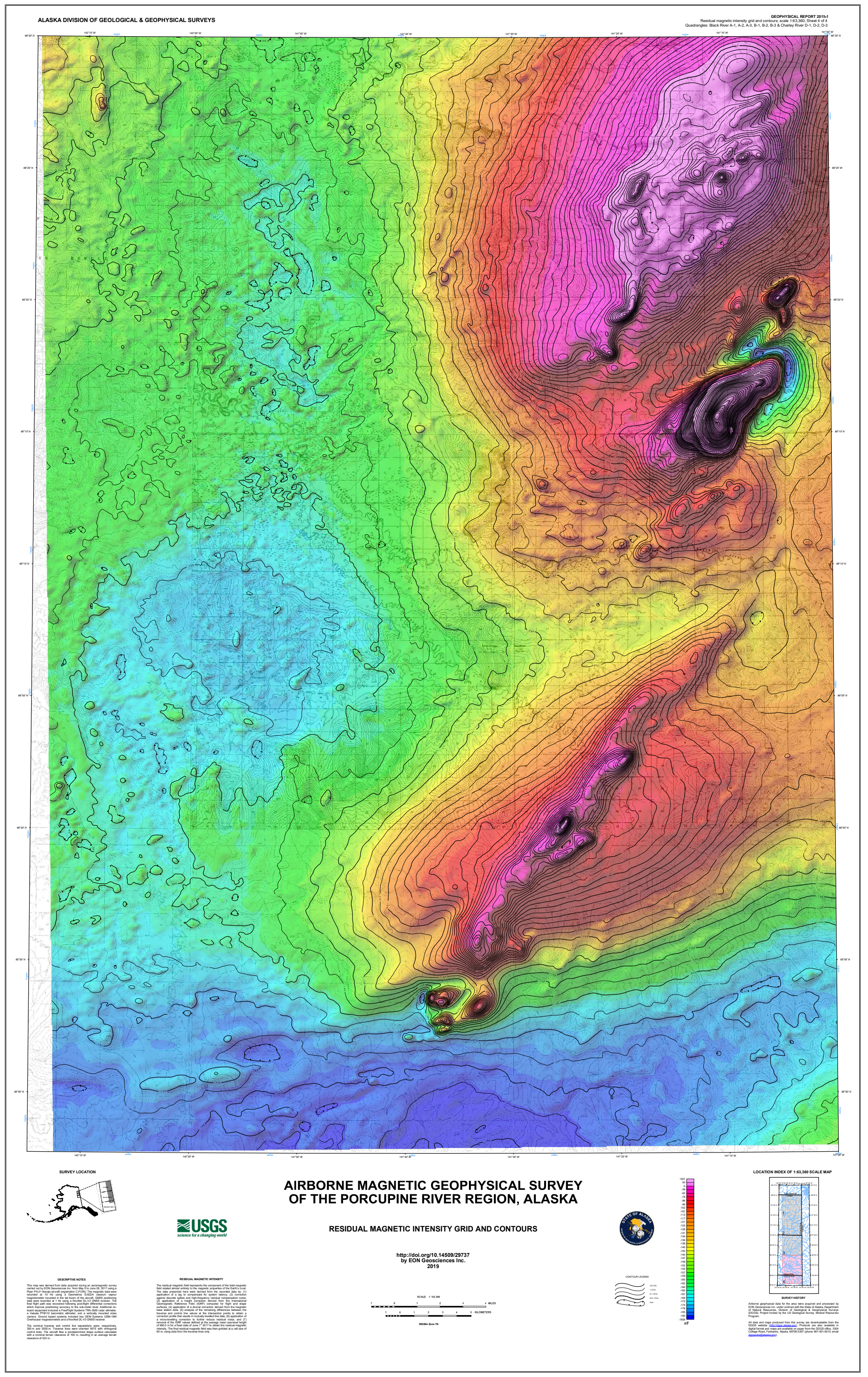



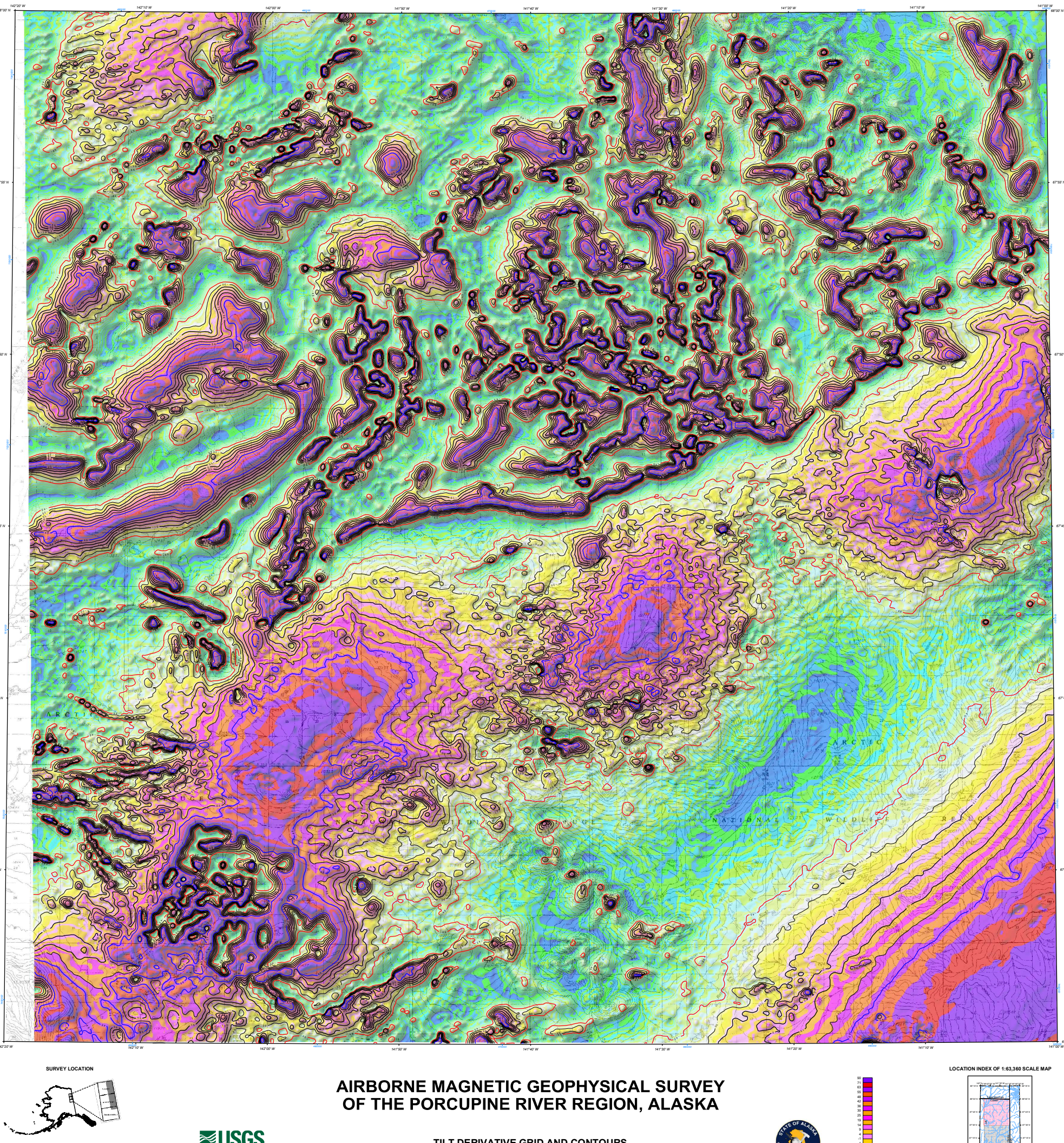

AIRBORNE MAGNETIC GEOPHYSICAL SURVEY OF THE PORCUPINE RIVER REGION, ALASKA

₹USGS

TILT DERIVATIVE GRID AND CONTOURS

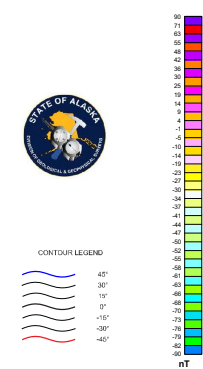

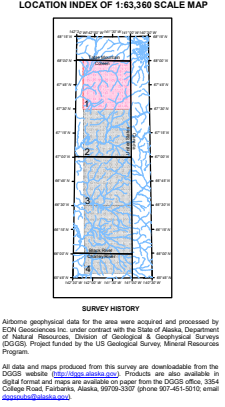




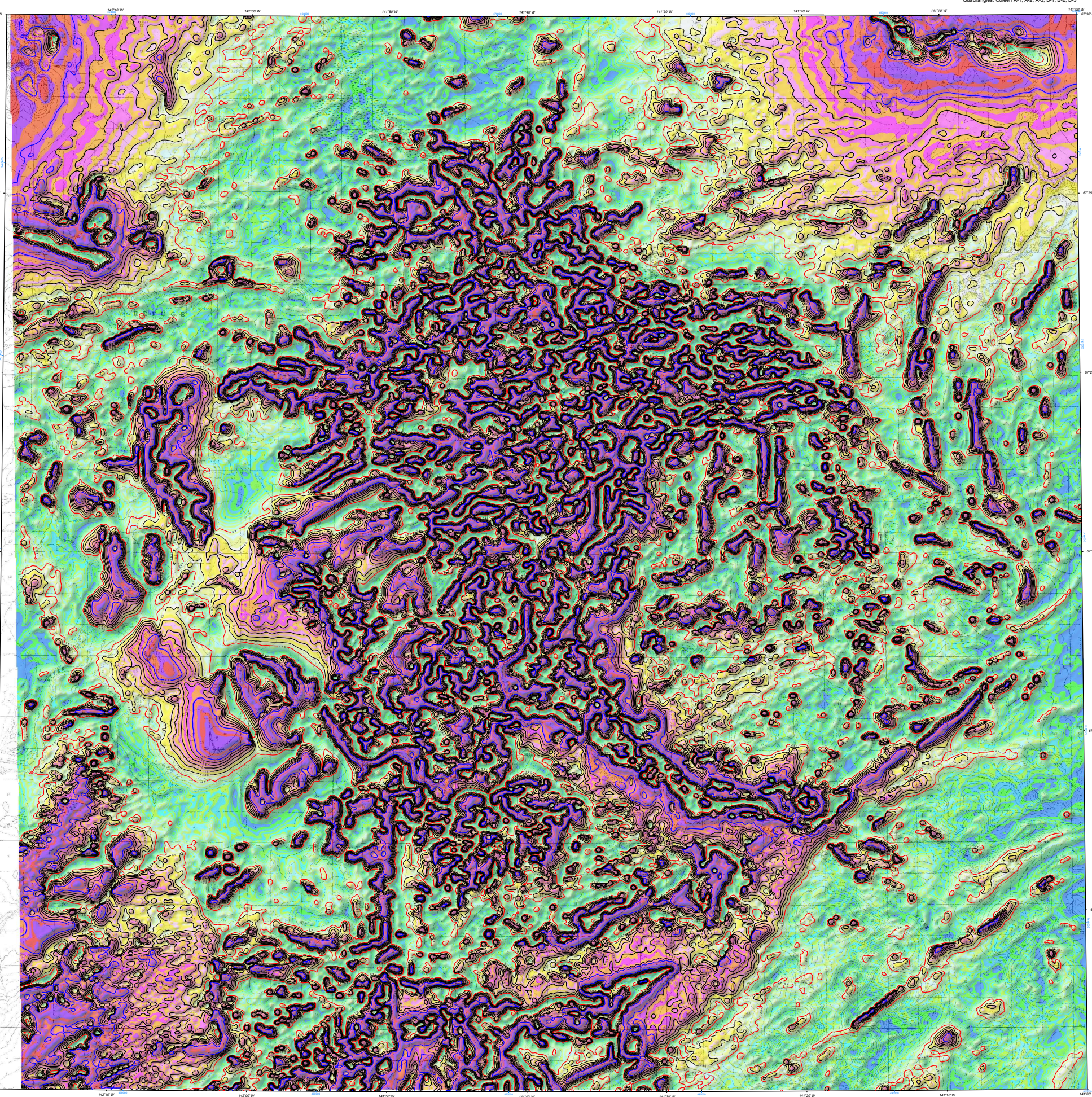

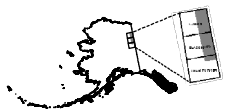

‡USGS
AIRBORNE MAGNETIC GEOPHYSICAL SURVEY OF THE PORCUPINE RIVER REGION, ALASKA

TILT DERIVATIVE GRID AND CONTOURS

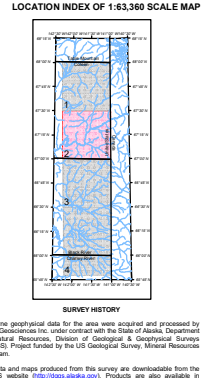

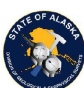




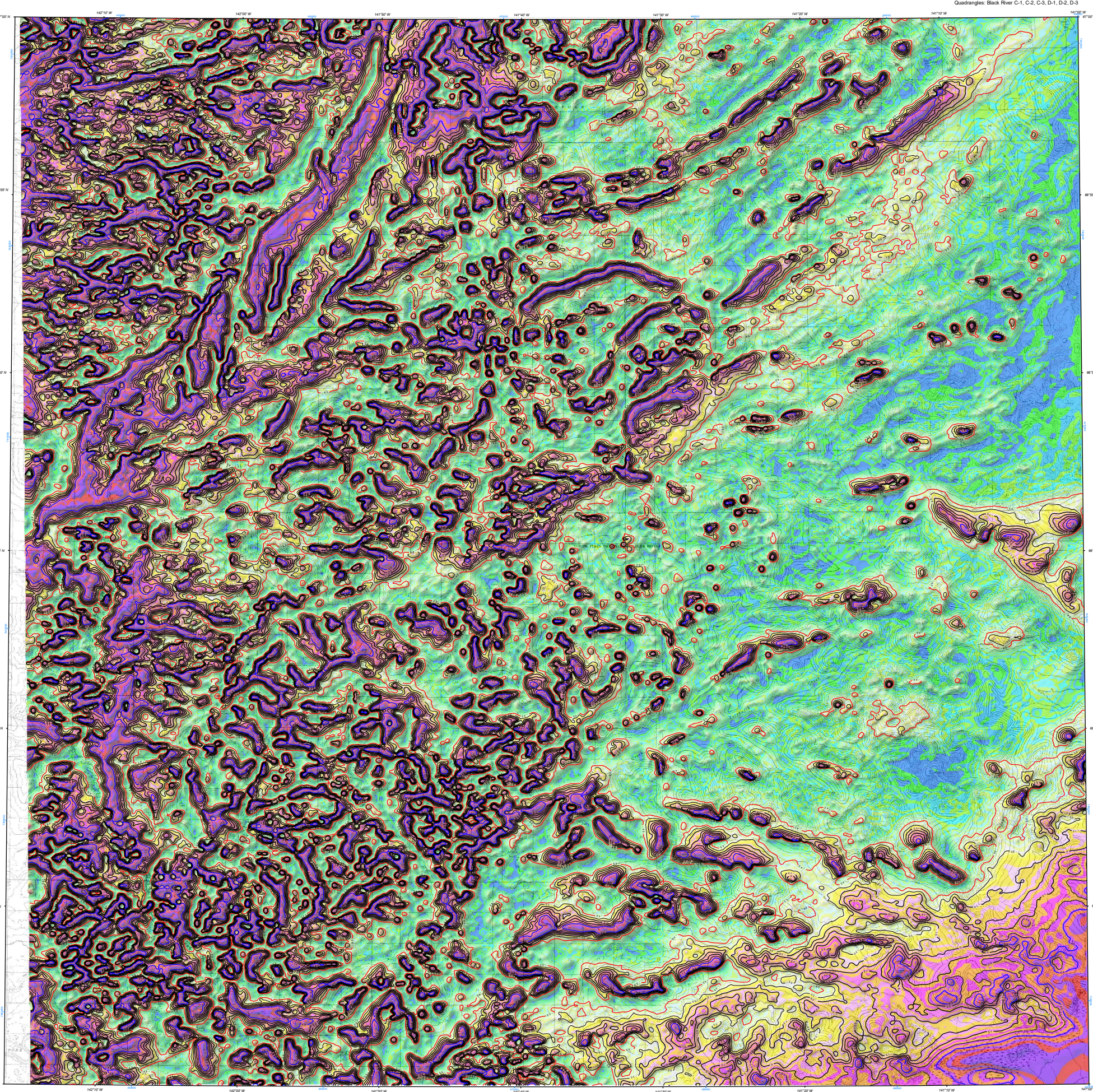

AIRBORNE MAGNETIC GEOPHYSICAL SURVEY OF THE PORCUPINE RIVER REGION, ALASKA

ॠUSGS 


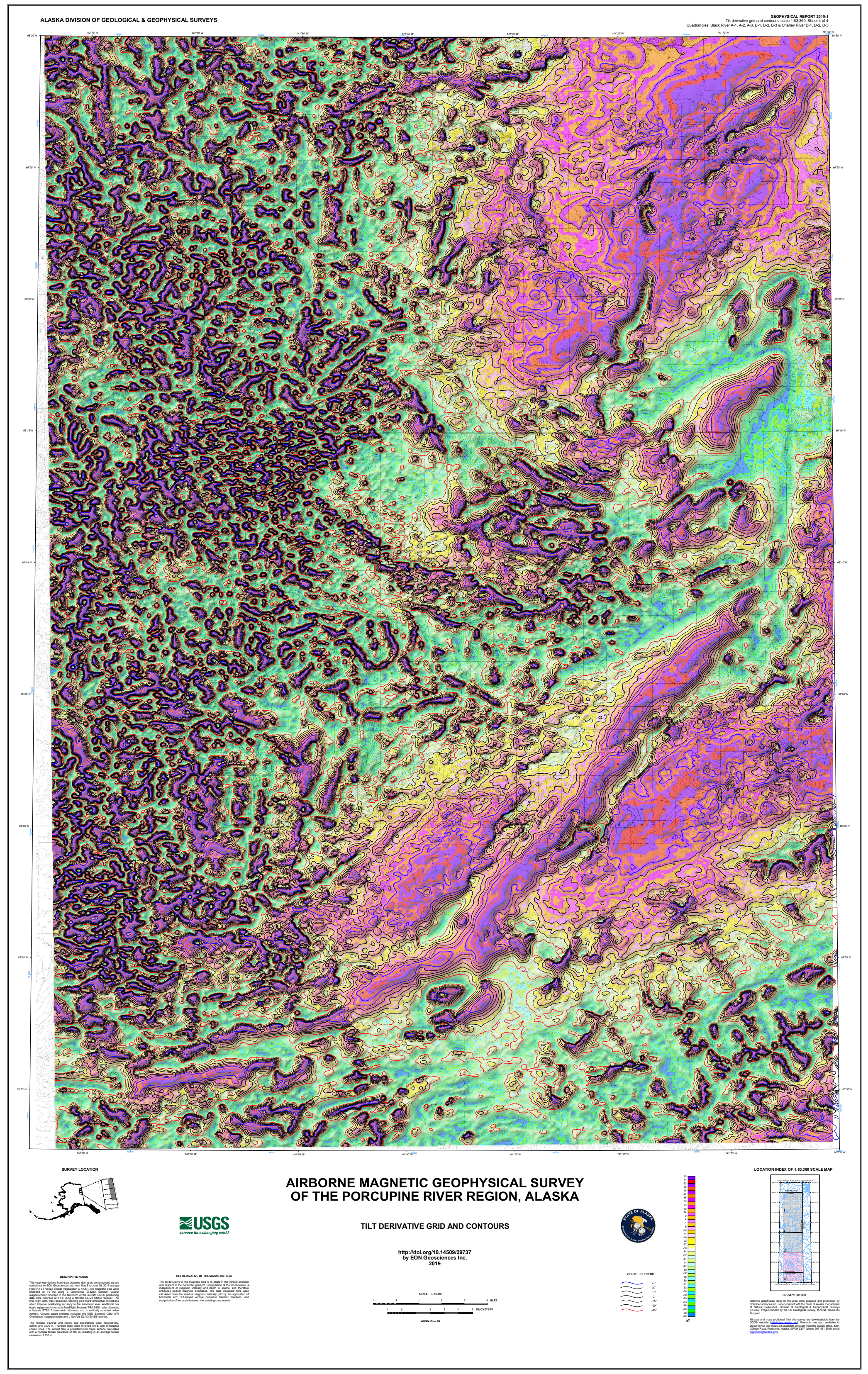

